T.C.

MARMARA ÜNIVERSITESI

SOSYAL BILIMLER ENSTITÜSÜ

İKTISAT (INNG) ANABİLIM DALI

İKTISAT (İNG) BİLIM DALI

\title{
TECHNOLOGY AND EMPLOYMENT
}

Yüksek Lisans Tezi

TOLGA AKSOY

İstanbul, 2008 
T.C.

MARMARA ÜNIVERSITESI

SOSYAL BILIMLER ENSTITÜSÜ

İKTISSAT (INNG) ANABİLIMM DALI

İKTISAT (INNG) BİLIM DALI

TECHNOLOGY AND EMPLOYMENT

Yüksek Lisans Tezi

TOLGA AKSOY

Prof. Dr. A. SUUT DOĞRUEL

İstanbul, 2008 
Marmara Üniversitesi

Sosyal Bilimler Enstitüsü Müdürlüğü

\section{Tez Onay Belgesi}

IKTISAT Anabilim Dalı IKTiSAT (ING.) Bilim Dalı Yüksek Lisans öğrencisi TOLGA AKSOY nIn TECHNOLOGY AND EMPLOYMENT adlı tez çalışması ,Enstitümüz Yönetim Kurulunun 07.07.2008 tarih ve 2008-11/25 sayllı kararıyla oluşturulan jüri tarafından oybirliğilo edilmiştir.

$\begin{array}{ll}\text { Tez Savunma Tarihi } & : 21.1 .07 .20 \% 8 \\ \begin{array}{ll}\text { 1) Tez Danışmanı : } & \text { PROF. DR. ALI SUUT DOĞRUEL } \\ \text { 2) Jüri Üyesi } \quad: & \text { PROF. DR. FATMA DOĞRUEL } \\ \text { 3) Jüri Üyesi } \quad: & \text { YRD. DOÇ.DR. HÜSEYIN TAŞTAN }\end{array}\end{array}$

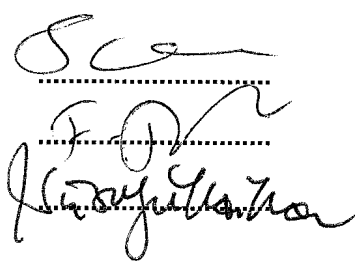


To my brother, Bülent Aksoy 


\section{ÖZET}

Teknolojik gelişmeler istihdamın kompozisyonunu tarih boyunca etkilemiştir. Endüstri devrimi sürecinde artan makinalaşma o güne kadar üretime egemen olan zanaatkârları (vasıflı işgücünü) ikame etmiş, vasıfsıı işgücüne dayalı üretim 20. yüzyılda ortaya çıkan Fordist üretim biçimiyle doruğa ulaşmıştır.

1980’li yıllardan itibaren, dünya ekonomisinde, daha eğitimli işgücünün sayısal olarak artması, iktisatçıları bu artışın nedenlerini araştırmaya itmiştir. Yapılan ampirik çalışmaların pek çoğu, teknolojik gelişmeyle vasıflı işgücü talebi arasında pozitif bir ilişki olduğunu ortaya koymaktadır. Son 30 yılda iletişim-bilişim devriminin ülke ekonomileri üzerinde yarattığı büyük etkiler nedeniyle, bu devrimin, Endüstri Devrimi'nin tersine, vasıflı işgücünü tamamlayan bir özelliğe sahip olduğu belirtilmektedir.

$\mathrm{Bu}$ çalışmada, endüstri ve iletişim-bilişim devrimlerinin istihdamın kompozisyonu üzerindeki etkisi incelendikten sonra, teknoloji ve vasıflı işgücü arasındaki ilişki, Türk özel imalat sanayii bağlamında, ampirik olarak test edilmiştir. Statik panel veri tahminin sonuçlarına göre, teknolojik gelişme ve vasıflı işgücü talebi arasında pozitif ancak zayıf bir ilişki bulunmaktadır.

Anahtar Kelimeler: Teknoloji, İstihdam, Panel Veri 


\begin{abstract}
Technological progress has influenced the composition of labor throughout history. Especially, increased mechanization within the process of Industrial Revolution substituted former masters of production, the craftsmen (skilled labor) and production based on unskilled labor reached its heyday in the Fordist system of production of the twentieth century.
\end{abstract}

Increase in more educated labor in the world economy has led economists to examine the determinants of this increase. Most of the empirical studies state that there is a positive relationship between technological progress and demand for skilled labor. In response to the great effects of Information and Communication Technologies (ICTs) Revolution on economies, it is pointed out that unlike Industrial Revolution, ICTs Revolution complements skilled labor.

In this thesis, after examining the effects of Industrial and ICTs Revolutions on labor composition, the relationship between technology and skilled labor is empirically tested for Turkish private manufacturing industries. According to the static panel data estimation results, there is a positive but weak relationship between technological progress and demand for skilled labor.

Keywords: Technology, Employment, Manufacturing Industry, Panel Data 


\section{PREFACE}

I am indebted to my supervisor Prof. Dr. A. Suut Doğruel for his encouragement together with continuous support throughout this study.

I would like to thank Prof. Dr. Fatma Doğruel and Asst. Prof. Dr. Hüseyin Taştan for their precious comments and contributions.

I am thankful to Dr. Ahu Karasulu for collaboration in organizing this thesis and P1nar Şener for her book assistance.

Finally, I would like to thank my fiancé, Meltem for her love and endless support. 


\section{TABLE OF CONTENTS}

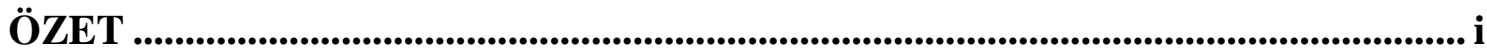

ABSTRACT.......................................................................................................................... ii

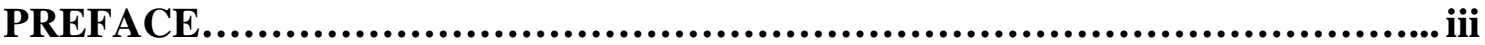

TABLE OF CONTENTS .............................................................................................. iv

LIST OF TABLES ................................................................................................................ v

LIST OF FIGURES .................................................................................................... vi

LIST OF ABBREVIATIONS ..................................................................................... vii

1. INTRODUCTION ....................................................................................... 1

CHAPTER 2. TECHNOLOGY AND EMPLOYMENT RELATION IN THE HISTORICAL CONTEXT ............................................................................................... 3

2.1. The Industrial Revolution ..................................................................................... 3

2.2. ICTs Revolution .................................................................................................. 10

CHAPTER 3. EMPLOYMENT AND TECHNOLOGICAL PROGRESS IN TURKISH PRIVATE MANUFACTURING INDUSTRY ........................................... 15

3.1. Developments in Turkish Manufacturing Industry .................................. 15

3.2. Sectoral Analysis of Turkish Private Manufacturing Industries........... 23

3.2.1. R\&D Based Analysis........................................................................ 23

3.2.2. ICTs Based Analysis ..................................................................... 29

3.2.2.1 The Growing Importance of ICTs.................................. 36

CHAPTER 4. EMPIRICAL ANALYSIS …............................................................... 40

4.1. Technological Change............................................................................................... 40

4.2. Literature Survey................................................................................................ 44

4.3. Data and Estimation Results............................................................................. 47

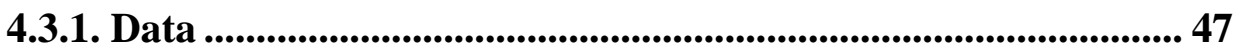

4.3.2. Model Specification and Empirical Results................................. 48

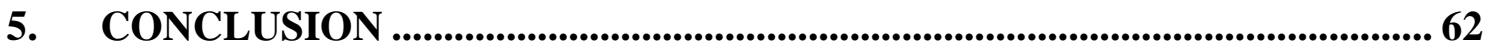

APPENDICES...................................................................................................................6 64

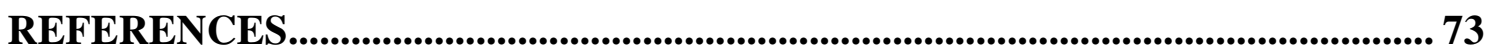




\section{LIST OF TABLES}

Table 3.1 Technical Workers and Technical Workers Ratio in Total Workforce in Turkish Private Manufacturing Industries (1992-2001)

Table 4.1 Estimating Nonproduction Labor Share Using Different Regression Models

Table 4.2 Estimating Technical Labor Share Using Different Regression Models 


\section{LIST OF FIGURES}

Figure 3.1: $\quad$ Sectoral Shares in Gross National Product (1980-2005) 16

Figure 3.2: Value Added Share in GNP and Fixed Investment Share in Total Fixed Investments of Manufacturing Industries (1980-2005)

Figure 3.3: Output and Employment Share of Private Manufacturing Industry in Total Manufacturing (1980-2001)

Figure 3.4: Details of Fixed Capital Investments in Turkish Private Manufacturing Industries (1995-2001)

Figure 3.5: $\quad$ R\&D Expenditures in Turkish Private Manufacturing Industries (1992-2001)

Figure 3.6: $\quad$ R\&D Shares For Selected Countries 21

Figure 3.7: Firm Shares According to R\&D Levels (1992-2001) 24

Figure 3.8: $\quad$ Production Shares According to R\&D Levels (1992-2001) 25

Figure 3.9: Employment Shares According to R\&D Levels (1992-2001) 26

Figure 3.10: Average R\&D Expenditures According to R\&D Levels (1995-2001) 27

Figure 3.11: Average Investments in Computer and Software According to R\&D Levels (1995-2001) 28

Figure 3.12: Skilled Labor Shares According to R\&D Levels (1992-2001) 29

Figure 3.13: Firm Shares According to ICTs Levels (1992-2001) 30

Figure 3.14: Production Shares According to ICTs Levels 31

Figure 3.15: Employment Shares According to ICTs Levels 32

Figure 3.16: Average R\&D Expenditures According to ICTs Levels (1992-2001) 33

Figure 3.17: Average Investments in Computer and Software According to ICTs Levels 34

Figure 3.18: Skilled Labor Shares According to ICTs Levels 35

$\begin{array}{ll}\text { Figure 3.19: } & \text { Skilled Labor and Skilled Labor Share in Turkish } \\ & \text { Private Manufacturing Industries (1992-2001) }\end{array}$

Figure 4.1: Technological Change and Production Functions $\quad 41$

Figure 4.2: $\quad$ Neutral and Biased Types of Technological Change 43

Figure 4.3: $\quad$ Skill Biased Technological Change 44

$\begin{array}{ll}\text { Figure 4.4: } & \text { Correlation Between Changes in Nonproduction Workers and } \\ & \text { Changes in R\&D Expenditures }\end{array}$

$\begin{array}{ll}\text { Figure 4.5: } & \text { Correlation Between Changes in Nonproduction Workers and } \\ & \text { Changes in Computer and Software Investments }\end{array}$

$\begin{array}{ll}\text { Figure 4.6: } & \text { Correlation Between Changes in Technical Workers and } \\ & \text { Changes in R\&D Expenditures }\end{array}$

Figure 4.7: Correlation Between Changes in Nonproduction Workers and 53 Changes in Computer and Software Investments 


\section{LIST OF ABBREVIATIONS}

$\%$

CAD

CAM

CIM

CNC

ENIAC

FE

FMS

GDP

GNP

ICTs

lbs

NICs

OECD

OLS

RE

R\&D

SBTC

SPO

TURKSTAT (TSI)

U.S.

WDI per cent

Computer Aided Design

Computer Aided Manufacturing

Computer Integrated Manufacturing

Computer Numerical Control

: $\quad$ Electronic Numerical Integrator and Computer

: $\quad$ Fixed Effects

: Flexible Manufacturing Systems

: Gross Domestic Product

: Gross National Product

: Information and Communication Technologies

: $\quad$ Libra

: $\quad$ Newly Industrialized Countries

: Organization for Economic Co-Operation and Development

: $\quad$ Ordinary Least Squares

: $\quad$ Random Effects

: $\quad$ Research and Development

: $\quad$ Skill Biased Technological Change

: $\quad$ State Planning Organization

: $\quad$ Turkish Statistical Institute

: $\quad$ United States

: World Development Indicators 


\section{INTRODUCTION}

The relation between employment and technology has been the subject of widespread debate since the Industrial Revolution. This debate has intensified in the last three decades due to several stylized facts. First, in the 1980s, American economists observed that skill premium (the wage differential by skill) was increasing in the United States. Moreover, demand for skilled workers was increasing despite the increase in wages. Second, the employment gap between high- and low-educated groups seems to be on the rise in practically all OECD countries (OECD, 2004). Third, the ratio of employment with primary education in total employment has a downward tendency in Turkey. The share declined from 74 per cent (\%) in 1997 to 58\% in 2005 (World Bank, World Development Indicators -WDI, 2008).

There were two major changes in world economy during the last three decades. First, world trade volume, and thus, trade between developed and developing countries have increased ${ }^{1}$. Second, pervasion of Information and Communication Technologies (ICTs) has radically influenced the sectoral composition of production. The share of services in gross production increased substantially ${ }^{2}$. In the same period, the commencement of the use of Computer Integrated Manufacturing (CIM) systems in

\footnotetext{
${ }^{1}$ U.S. imports from less-developed countries were 0.4 percent of Gross National Product (GNP) in 1970, before rising to 2.5 percent of GNP in 1990. In addition to this, in the European Union, imports from lessdeveloped countries increased from 0.5 percent in 1970 to 2.1 percent of GNP in 1990 (Freeman, R., B., 1995).

${ }^{2}$ In U.S. the share of value added of services in Gross Domestic Product (GDP) is $62 \%$ in 1971, $70 \%$ in 1990 and $75 \%$ in 2000 . The employment share of services in total employment is $66 \%$ in $1980,71 \%$ in 1990 and $74 \%$ in 2000. In Euro area, the share of services value added in total GDP is $53 \%$ in 1971, 64\% in 1990 and $70 \%$ in 2000 . The employment share of services is $52 \%$ in $1981,58 \% 1991$ and $64 \%$ in 2000 (Source: WDI, 2008).
} 
manufacturing has lead to major developments in manufacturing industries. As these developments occurred simultaneously with the increases in demand for skilled labor, explanations were sought either in trade or technology.

In response to those stylized facts, a great volume of empirical studies have been carried out (mostly for United States -U.S.) in the late 1980s and during 1990s in order to explore the determinants of rising demand for skilled labor. Empirical studies to this end fall into two categories: they seek explanation either from a labor perspective or a trade perspective ${ }^{3}$. The labor perspective states that new technologies are by their nature complementary to skills and the recent past witnessed rapid introduction of new technologies, leading to acceleration in skill bias (Acemoğlu, 1998). Therefore, the main contributor to the wage inequality is the technological progress.

The aim of this thesis is not to analyze determinants of wage inequality but to analyze whether technology complements or substitutes labor. Turkish private manufacturing industries are investigated in the thesis. The studies that are mentioned above have mostly concentrated on developed countries. Yet, this thesis concentrates on the case of a developing country and attempts to contribute to this literature, filling this very shortcoming. To this end, in the second chapter of the thesis, the relationship between technology and employment will be examined within the historical perspective. In the third chapter, Turkish manufacturing industries are analyzed with a special focus on its technological features. The fourth chapter is the empirical analysis and the fifth chapter is the conclusion.

\footnotetext{
${ }^{3}$ Our perspective is based on Labor Approach and Trade Approach is beyond the scope of this thesis. Yet, it is convenient to state that trade-based studies are based on Hecksher-Ohlin model and defense that increasing demand for skilled labor occurs because of increasing trade rather than technological progress. See Slaughter (1998) for a survey of trade based studies.
} 


\section{CHAPTER 2}

\section{TECHNOLOGY AND EMPLOYMENT RELATION IN THE HISTORICAL CONTEXT}

The effects of technological progress on composition of labor varies with the nature of technology. Caselli (1999) states that technological revolution is de-skilling if the new skills can be acquired at a lower cost than the skills associated with preexisting technologies. Yet, technological revolution is skill-biased if the new skills are more costly to acquire than the skills required by preexisting type of equipment.

The subject of this chapter is the evolution of the relationship between technology and employment within the historical perspective. In this respect, first the Industrial Revolution, and then ICTs Revolution that was dominant in the second half of the twentieth century will be examined.

\subsection{The Industrial Revolution}

The major innovation of the Industrial Revolution was the substitution of steam power for water power and animal muscle power (Ayres, 1991, p.29). This new energy source greatly affected the mining, metallurgy and textile sectors. The coal production was 200 thousand tons in 1550s, whereas it reached to 10 million tons in 1800s (Güran, 1999, p.117). The textile sector was based on the putting-out system during the feudal 
era. Invention of the cotton-textile machine working with steam power contributed to the expansion of the sector. Thanks to these improvements, the demand for raw cotton of England increased extremely. Imports of raw cotton grew from an average of 16 million $\mathrm{lbs}^{4}$ pa in $1783-1787$ to 29 million $\mathrm{lbs}$ in $1787-92$ and 56 million in 1800 as the source changed from the West Indies to the United States slave plantations (Freeman and Soete, 2000, p.37-38).

While the Industrial Revolution gave rise to enormous increases of output, it also contributed to the changing of economic and social systems. By decreasing of employment in agricultural production, the share of employment in industry and the share of industrial output in total production increased substantially. Socially, this gave rise to urbanization, and economically, to factory production ${ }^{5}$. Thus, the major outcome of the Industrial Revolution was the increase in the urban population working in the factories, and hence an increase in urbanization.

Although the Industrial Revolution started by the invention of steam engine, it was not ended by it. On the contrary, eighteenth and nineteenth centuries witnessed the various types of inventions and these inventions led to increased mechanization. The mechanization of production was rationalized with the factory production. As cities were unskilled labor abundant (early peasants came from villages), entrepreneurs employed these new workers. Classical economists examined the employment impacts of mechanization (technological change) and offered compensation mechanism. In other words:

\footnotetext{
${ }^{4}$ Libra, an English unit of weight $=0.4536 \mathrm{~kg}$.

${ }^{5}$ Factories were built in the cities that were abundant with labor force and have cheap coal.
} 
The class of labourers [just as landlords and the capitalist who made the discovery of the machine] also, I thought, was equally benefited by the use of machinery, as they would have the means of buying more commodities with the same money wages, and I thought that no reduction of wages would take place, because the capitalist would have the power of demanding and employing the same quantity of labour as before, although he might be under the necessity of employing it in the production of a new, or at any rate of a different commodity... There would be the same demand for labour as before, and that wages would be no lower, I thought that the labouring class would, equally with the other classes, participate in the advantage, from the general cheapness of commodities arising from the use of machinery (Ricardo, D., 2001, p. 392393).

Yet, a discussion of the effect of these innovations on skilled and unskilled labor is crucial to the analysis in this thesis, as such like an effect parallels the impact of technology on employment.

Eighteenth and early nineteenth centuries of new technologies replacing rather than complementing skills, such as the spinning jenny, weaving machines, Jacquard's loom, printing cylinders, and later the assembly line (Acemoğlu, 1998). For instance, in the cotton factories, the employment of a few skilled male workers were enough for production, and it was possible to receive the rest of the necessary labor from unskilled and low-wage women and children. (Güran, 1999, p.118). Nevertheless, the best deskilling technological change example is the Fordist production system.

The Fordist production system, exists between the Industrial Revolution and ICTs Revolution, should be examined clearly as it dominated the world economy from the early 1900s to 1970s. "This system was firstly implemented by Henry Ford in his Highland Park plant in Detroit. Between 1908 and 1914 he gradually eliminated craftmade components in the manufacture of the Model T and this process culminated with the introduction of the moving assembly line itself in 1913" (Freeman and Soete, 2000, p.138). By the combination of organizational, social and technical innovations (Freeman 
and Soete, 2000, p.141), the price of a model T fell from $\$ 850$ in 1908 to $\$ 600$ in 1913 and \$360 in 1916.

The Fordist system was based on mass production. In this system, "there is a tendency for both physical output per plant and productivity per worker to increase steadily over time. The competitiveness is based on substantial reductions in the unit cost of commodity" (Duruiz and Yentürk, 1992, p.20). While Ford was producing car on a very large scale, unit costs had dropped sharply (Ayres, 1991, p.34) and the sales of model T increased fifty times over and market share increased from 10 per cent in 1909 to 60 per cent in 1921 (Freeman and Soete, 2000, p.141).

As Freeman and Soete (2000: 139) points out, the triumph of mass production was achieved only after a very painful period of worldwide structural adjustment in the 1920s and 1930s. It is because, "the physical and technical features of Fordism required regular consumer behavior in one hand and large and stable markets on the other; large enough markets to absorb big volumes of output of standardized commodities and stable markets, to ensure the amortization of investment costs and constant employment of the factors of production" (Duruiz and Yentürk, 1992, p.20). Thus, by the realization of Keynesian policies in welfare states in the post-war period; consumer credit arrangements, new wage structures, deficit spending, subsidized consumption, aid for reconstruction (Freeman and Soete 2000, p.139; Duruiz and Yentürk, 1992, p.23) harmonized the new technological potential and socio-institutional frameworks. As a result, the post-war period (1950-1970) has witnessed the great economic growth (The Golden Era). 
A historical analysis indicates that the relationship between technology and employment is bilateral. First of all, technology affects the labor composition either by complementing or substituting. Secondly, technology affects organization of labor in the workplace.

From the first viewpoint, we define Fordist production characteristic of assembly line is a kind of de-skilling technological change. Despite the above-mentioned examples of de-skilling through Industrial Revolution, craft-based production continued in some areas until twentieth century, which was defined as hybrid or late craft system by Freeman (2002, p.273). This system persisted until the introduction of interchangeable-parts, ${ }^{6}$ which allow substituting unskilled assembly workers for skilled machinists. Türkcan (1981: 124) states that production of interchangeable parts was the second most important stage of the factory system after applying steam power to machine. It is because, as long as parts were irregular in shape and not machined to a precise specification, skilled craftsmen were required to fit the parts and assemble each product (Freeman and Soete, 2000, p.137-138) and only with interchangeable parts, machines could be produced incessantly in a factory just as consumer goods (Türkcan, 1981, p.124) which means standardization. The machining of parts was reduced to a few simple operations by the redesign of the tools and presses to carry out one simple repetitive task each. As a result, the need for skilled workers was reduced to a minimum and the plant was controlled and coordinated by the new profession of industrial (production) engineers and an army of foremen and indirect workers responding to their orders (Freeman, 2002, p.276).

\footnotetext{
${ }^{6}$ For example screws and hour wheels.
} 
Goldin and Katz (1998) gives the example of automobile industry of U.S. Until the assembly line system, automobiles were produced in large artisanal shops. In these shops, automobiles were assembled by craftsmen who hand-fitted the various pieces. However, with the assembly line system, the relative demand for skilled workers declined as technological progress led the production process standardized.

Not only technological improvements, but also managerial characteristics of Fordism also contributed to de-skilling. With fragmentation of tasks and more detailed division of labor, tasks were broken down and simplified further, removing previous skill requirements for the job. In addition to this, control over all aspects of production is exercised by management through a hierarchical chain of authority (Allen, 1996). Discipline was strict and unions were banned (Freeman, 2002, p.276). In the Fordist system, the labor force has nothing to contribute to the production process. As Womack et al. (1990) suggests:

The assembler on Ford's mass production line had only one task-to put two nuts on two bolts or perhaps to attach one wheel to each car. He didn't order parts, procure his tools, repair his equipment, inspect for quality, or even understand what the workers on either side of him were doing. Rather he kept his head down and thought about other things. The fact hat he might not even speak the same language as his fellow assemblers or the foreman was irrelevant...the assemblers required only a few minutes training (Womack et al., 1990, p. 31 as cited in Freeman and Soete, 2000, p. 143-144).

The Fordist system came to an end in the 1970 s by the collapsing of world economic system-the energy crises, Keynesian welfare states' problems, increasing competition of Japan and the Newly Industrialized Countries (NICs). Although these reasons are very important, it is more appropriate to state that the Fordist system came to an end by the combination of its natural problems and world economic problems. 
First, Fordist system caused displeasure of the workers. The speed of line, the boring nature of the work and other unpleasant features of employment, such as the work discipline, led to an extremely high turnover of labor during the first year of operation. In 1913, labor turnover reached nearly 400 per cent so that Ford was obliged on 5 January 1914 to introduce the '5-dollar day' which meant in effect that the wages of Ford workers were doubled (Freeman and Soete, 2000, p.144).

Second, some defective parts were inevitable feature of the Fordist system. "The solution adopted was not to improve the skills or responsibilities of the production line workers but to have an inspection and 'rework' department at the end of the line. Hence, defective products caused customer complaints" (Freeman and Soete, 2000, p.144).

Third, in the Fordist system, "all machines were connected to each other. If every machine operated perfectly, without any breakdowns, the automated plant could operate continuously, 24 hours a day. In practice, however, breakdowns of various kinds are a fact of life, and the plant must be organized to cope with them. When a machine does stop for some reason, all machines in the line to which it is linked must also stop until the problem is corrected"' (Ayres, 1991, p.69-70).

Fourthly and the most importantly, the assembly line is extremely inflexible; therefore, it is too costly to produce different types of commodities. Ayres (1991, p.75) gives the Ford example; each plant is essentially custom-designed to produce a single family of car bodies. That is, any change in the design of the car means a new plant has to be built. However, every such plant is unique. As a result, this inflexibility caused 
enormous costs for Ford Motor Company. When Ford converted from the Model $\mathrm{T}$ to Model A in 1926, the cost of that conversion was \$25 million. Moreover, when Ford introduced Mustang in 1963, the conversion cost was \$59 million (1958 \$), while cost of introducing the Fairmont and Zephyr models in 1977 was $\$ 600$ million.

All of the features of the Fordist system became incompatible with the economic conditions in 1970s. Large and stable markets are no longer available so that mass production is no longer available which meant that unit costs would be higher. On the other hand, after 1970s, with the increasing wealth of nations, consumer demand on durables diversified. As it is mentioned above, in the Fordist system, different types of commodities are too costly to produce. That means, producers could not adjust to the consumers demand. The adjustment became available only with the new organizationpost Fordist system.

\subsection{ICTs Revolution}

The post-fordist production techniques overcame the crisis and became dominant since the late 1970 s. The key word is flexibility-the ability to change or react with little penalty in time, effort, cost or performance. Instead of standardized, oneproduct-fits-all, high volume production, firms aim toward market niches, 'mass customization' and the goals of product innovation and quality (Malecki, 1997, p.129). The flexibility, dominated production system for three decades, has two dimensions. Firstly, it means the changing of labor organization. Secondly and more importantly, Flexible Manufacturing Systems (FMS) are related with the ICTs Revolution. 
In the eighteenth and nineteenth centuries, innovations were driven by individual inventors. However, in the twentieth century, innovations were driven by professional Research and Development (R\&D) departments within the firm, by qualified scientists as well as engineers with scientific training. That means, during the twentieth century, main locus of the inventive activity shifted away from the individual inventor to the professional R\&D laboratory, whether in industry, government or academia. For instance, Von Neumann worked closely as a consultant with the corporate R\&D departments of innovating firms. It is because the industries which the scientists work for technology is science based, in the sense that it could not have been developed at all without a foundation in theoretical principles (Freeman and Soete, 2000, p.198-199). Equally important is the fact that, throughout the two world wars and during the Cold War period, governments supported R\&D activities for military purposes. Especially after the World War II- in the Cold War era- researches such as space exploration and nuclear weapons, received a relatively generous increase in funding in many countries (Freeman and Soete, 2000, p.375). The most important invention of the twentieth century that was a result of military concern is the invention of computer. The importance of computer is that it affects the whole economy instead of only one sector. As Ayres (1991) states:

The first electronic computer built by a team leader led by J. Presper Eckert and John Mauchley at the Moore School of Engineering at the University of Pennsylvania. The project began in 1944 under military sponsorship, and the result, known as Electronic Numerical Integrator and Computer (ENIAC), was publicly unveiled in 1947. The developers of ENIAC went on to build the first commercial computer, UNIVAC I which appeared in 1950. However, electronic computers were too expensive, too hard to program and much too unreliable for most purposes. They were not directly applied to manufacturing problems until two more decades had passed (Ayres, 1991, p.85). 
However, with the improvements in semiconductors and microprocessors, electronic devices became much smaller, cheaper and faster. Microprocessors were successfully adapted to machine tools (and robots) in 1970s. Developments in software technology and rapid technological progress in microelectronics conduced to the creation of new manufacturing technologies (more flexible machine controls), called CIM systems or FMS. The tools of CIM systems are Computer Numerical Control (CNC), Computer Aided Design (CAD) and Computer Aided Manufacturing (CAM). As the average cost of these tools declined, they started to be used widely.

As it is underlined above, the inflexibility of the assembly line is one of the reasons for the end of an era of mass production. Whenever the product is changed, the specialized machine must be rebuilt. With computer technology, however, the equipment (the hardware) is adapted to the operation by the computer program (the software); therefore the equipment can be put to new uses by reprogramming (Piore and Sabel, 1984, p.260). These features of CIM systems rendered it possible to pass to flexible production from mass production.

Freeman (2002: 313) states that Diebold (1952) envisaged many of applications of computers but had pointed out that they could be successfully developed and used only after a prolonged period of training people with new skills, reorganizing management systems, and redesigning production processes. As envisaged long before, ICTs affected both labor composition and organization of the labor in the workplace. Firstly, the type of workers that FMS needed changed since the manufacturing process was replaced by FMS. New machines, as expected, were implemented by the motivation of reducing labor cost (Ayres, 1991, p.87). However, their crucial impacts 
were occurred upon the skill levels of the labor force. ICTs Revolution substituted CIM systems for semiskilled and low skilled workers such as machine loaders, operators and assemblers (Ayres, 1991, p.90) and led to new priorities regarding worker skills, requiring multi-skilling, or polyvalent skills, and continuous, rather than minimal and narrow training (Malecki, 1997, p.138) and redirected progress down the path of craft production. In other words, the advent of the computer restored human control over the production process; machinery is again subordinated to the machinist (Piore and Sabel, 1984, p.261).

Malecki (1997: 133-134) points out that flexibility is much more an organizational property than a technical one. The centralized, hierarchical structure of Fordist production was eroded with the universal availability of personal computers, the introduction of local area networks (LANs), and the rapid changes in product and process design (Freeman, 2002, p.326). Jobs and specific work tasks were knowledgebased, independent and controlled by workers than under the traditional Fordist rules (Malecki, 1997, p.141), as a result, horizontal, de-centralized organization forms became dominant in the workplace.

The above-mentioned history should not be taken as a spontaneous development. There are numerous studies that attempt to theorize this history. Relevant to the subject of this thesis is, for example, Acemoğlu (2002) who underlines 'market incentives' and 'endogenous technological change'. By quoting Schmookler (1966), he states that market size was crucial in determining the directions of technical change and the development and use of the technology is a response to profit incentives. Early nineteenth century was characterized by skill replacing developments because the 
increased supply of unskilled workers in the English cities (resulting from migration from rural areas and from Ireland) made the introduction of these technologies profitable. On the other hand, when skill biased techniques are more profitable, firms will have greater incentives to develop and adopt such techniques. New technologies have become more skill-biased throughout most of the twentieth century because the supply of skilled workers has grown steadily. This approach is consistent with the example of Freeman and Soete (2000, p.57), which states that the shortage of skilled labor in the eighteenth and nineteenth centuries in U.S. led American entrepreneurs and engineers to seek the production techniques which would both substitute machinery for labor and facilitate the use of fewer skilled craft workers relative to the unskilled and semiskilled. 


\section{CHAPTER 3}

\section{EMPLOYMENT AND TECHNOLOGICAL PROGRESS IN}

\section{TURKISH MANUFACTURING INDUSTRY}

In this chapter, we study both the fundamental characteristics and the employment structure of Turkish manufacturing industries. By doing so, we attempt to give a brief historical review of industrial developments in Turkey in the post 1980 period. Since our empirical examination covers the years between 1992 and 2001, we prefer to investigate $1980-2005$ period and exclude the planned economy years (19631980 period).

\subsection{Developments in Turkish Manufacturing Industry}

After pursuing planned economy and import substituting industrialization strategy between 1963 and 1980, Turkey passed to export promoting industrialization strategy in $1980^{7}$. The objective of the new strategy was to economize the balance of payment deficits by increasing export and industrialize the country. It forms the topic of this part; how this strategy did affect the industry sector, employment and technological progress when it was applied.

\footnotetext{
${ }^{7}$ Although industry sector succeeded greatly in the planned economy phase, it witnessed some problems in the late 1970s. As this strategy requests attainability of intermediary and investment goods, overvalued exchange rate policy was implemented. On the other hand, this policy penalized the export potential of the industry. Kepenek and Yentürk (2004: 363) states that, during this period, the export of industry could not increase substantially and the increasing balance of payment deficits confronted the country with external debt problems. Since these problems combined with the political instability, a new industrialization strategy became inevitable.
} 
Figure 3.1: Sectoral Shares in Gross National Product (1980-2005)

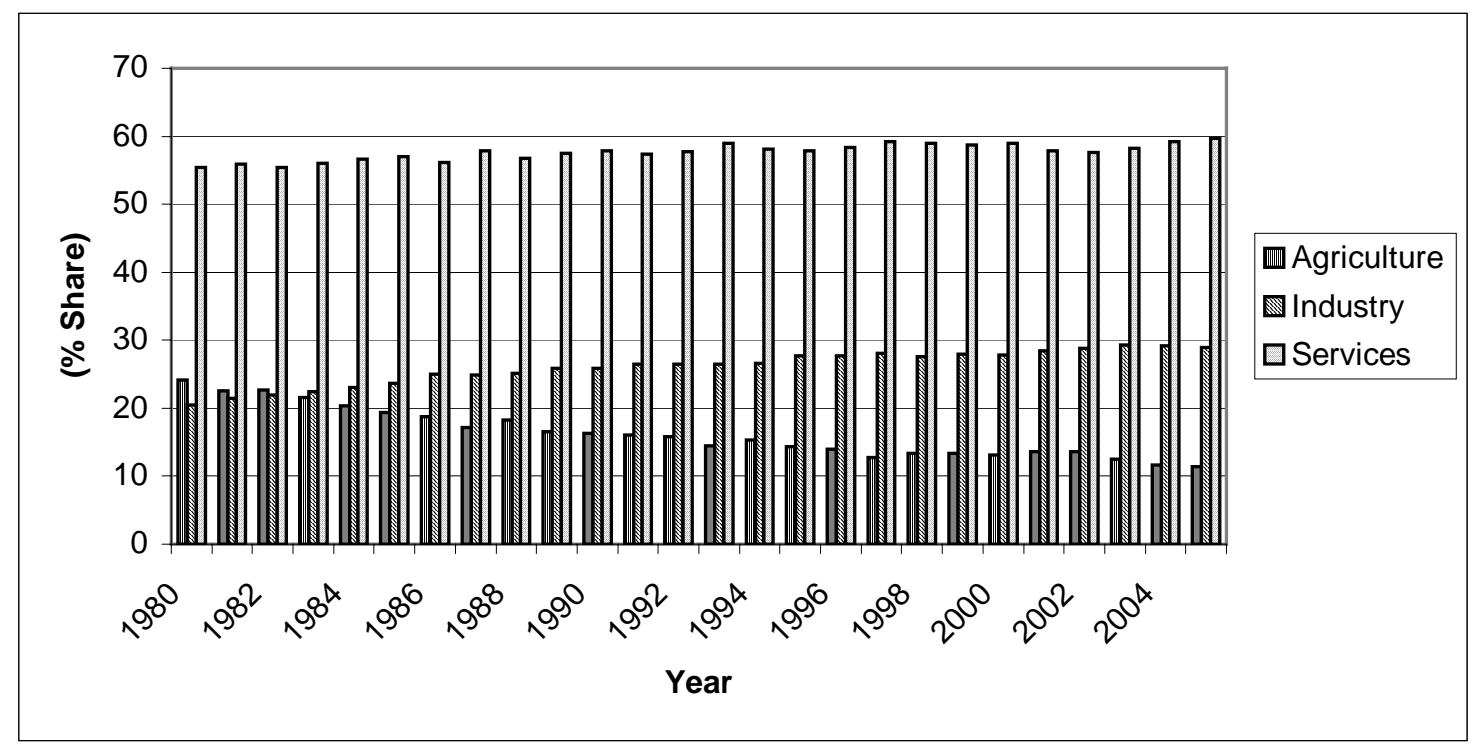

Source: Turkish Statistical Institute (TURKSTAT), 2006

If the compound of Turkish national product is investigated, it is realized that the proportion of agriculture gradually decreased in the past 25 years. As it is demonstrated in Figure 3.1, there is an upward tendency in the proportion of industry and a downward tendency is seen in the proportion of agriculture. Meanwhile, the services sector keeps on following its prominence in the economy. Agriculture sector, which formed $24.2 \%$ of national product in 1980 , has a portion of $11.4 \%$ in 2005 . On the other hand, the shares of industry and services sectors have increased to $8.4 \%$ and $4.3 \%$ respectively over the period. Industry sector, which has the share of $19.3 \%$ in planned economy years, had the share of $25 \%$ between the years of $1980-2005$ and forms the $30 \%$ of national product concerning 2005. 
Figure 3.2: Value Added Share in GNP and Fixed Investment Share in Total Fixed Investments of Manufacturing Industries (1980-2005)

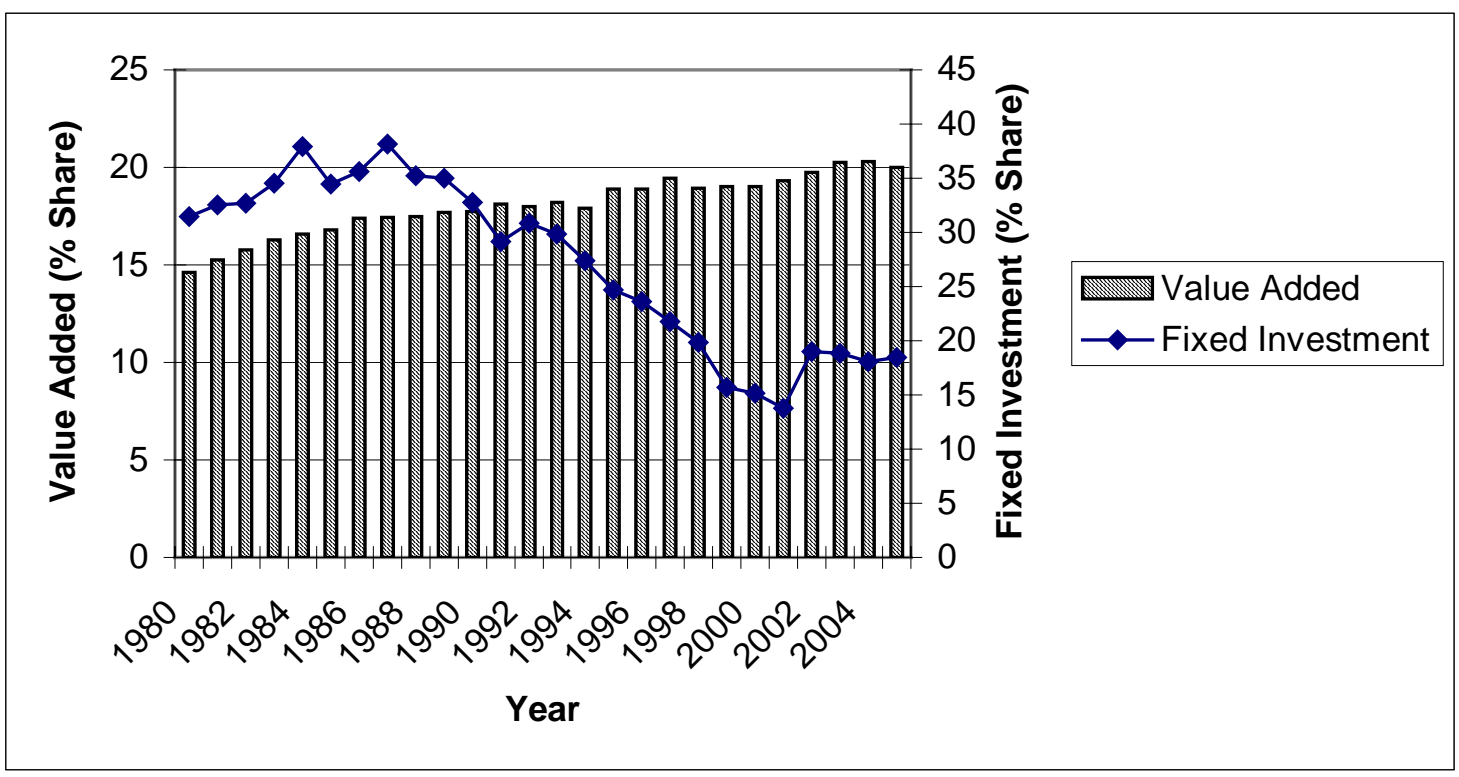

Source: State Planning Organization (SPO), <http://www.spo.gov.tr>

When we examine the manufacturing industries in detail, we see that value added of total manufacturing industries increased in the share of national product. As we see in Figure 3.2, the share of $14.6 \%$ in 1980 , has increased to $17.7 \%$ in $1990,19 \%$ in 2000 and $20 \%$ in 2005 . When we look over the share of manufacturing industries investments in total fixed capital investments, we realize a considerable decrease especially in the period of 1990-2001. 
Figure 3.3: Output and Employment Share of Private Manufacturing Industries in Total Manufacturing (1980-2001)

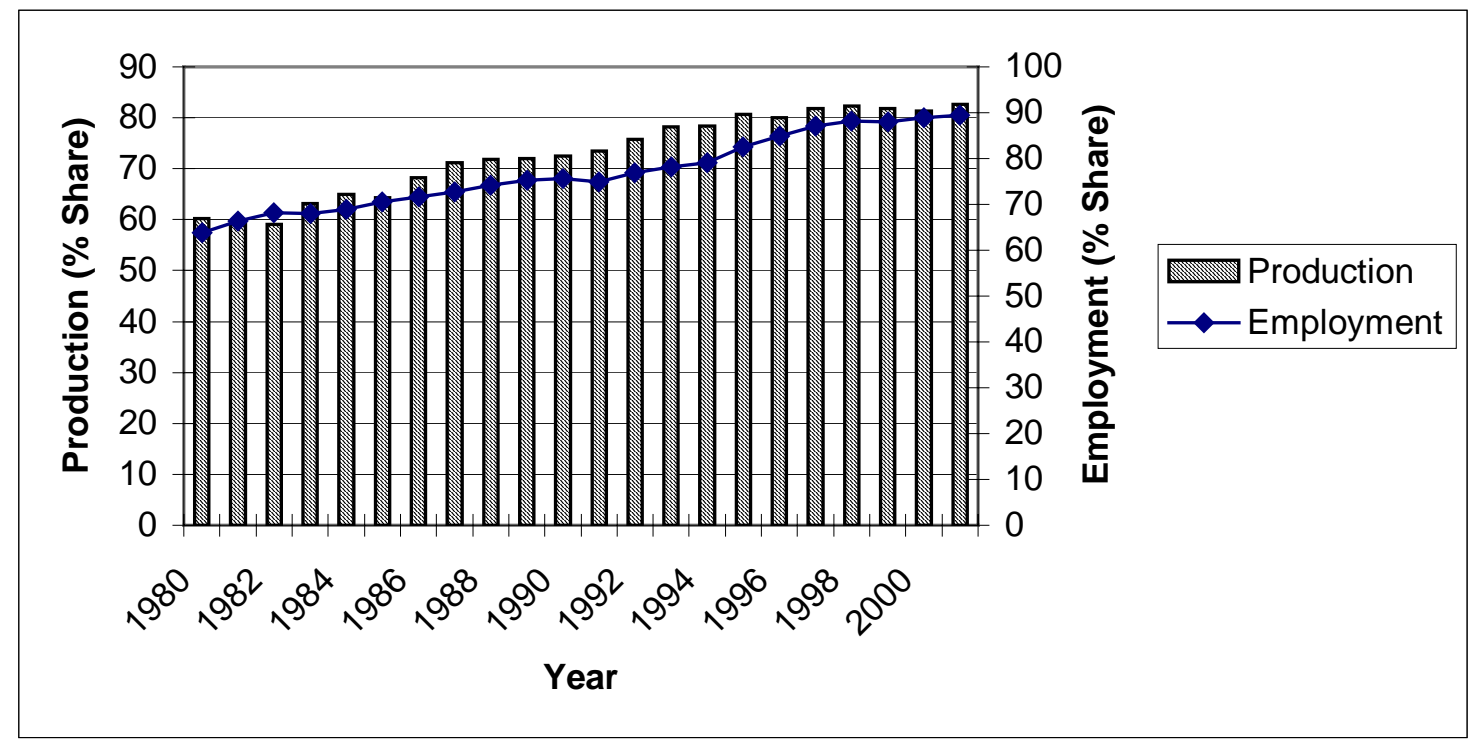

Source: TURKSTAT (2006)

In the empirical part of the study, private manufacturing industries will be analyzed. Because of that, we want to examine the developments in private manufacturing industries. In Figure 3.3, production and employment shares of private manufacturing industries in total manufacturing industries are displayed. As it is seen, there is an upward tendency in the share of private manufacturing industries. That share has increased to $82.5 \%$ from 1980 to 2001 by increasing $22.5 \%$. Besides, in the crisis years of 1994 and 2001, increasing of production share of private manufacturing industries is remarkable. It is fair to say that employment has a similar upward tendency. The share of private manufacturing industries employment in the area of total manufacturing has increased to $26 \%$ in the process of 22 years. And, almost $90 \%$ of employees of Turkish manufacturing industries are working in private sector in 2001 . In addition to these, the increase in employment share of private manufacturing industries is remarkable in the crisis years of 1994 and 2001. 
One of the other aims of this chapter is to analyze the basic qualifications of manufacturing industries, in the sense of technology. As pointed out before, ICTs Revolution made a radical reform in the process of manufacturing, by coming on using CIM systems in manufacture: both organizational and employment. Therefore, before analyzing qualitative side of employment, it is better to analyze and investments in computer and software and R\&D expenditures in private manufacturing industries.

Figure 3.4: Details of Fixed Capital Investments in Turkish Private Manufacturing Industries (1995-2001) (a)

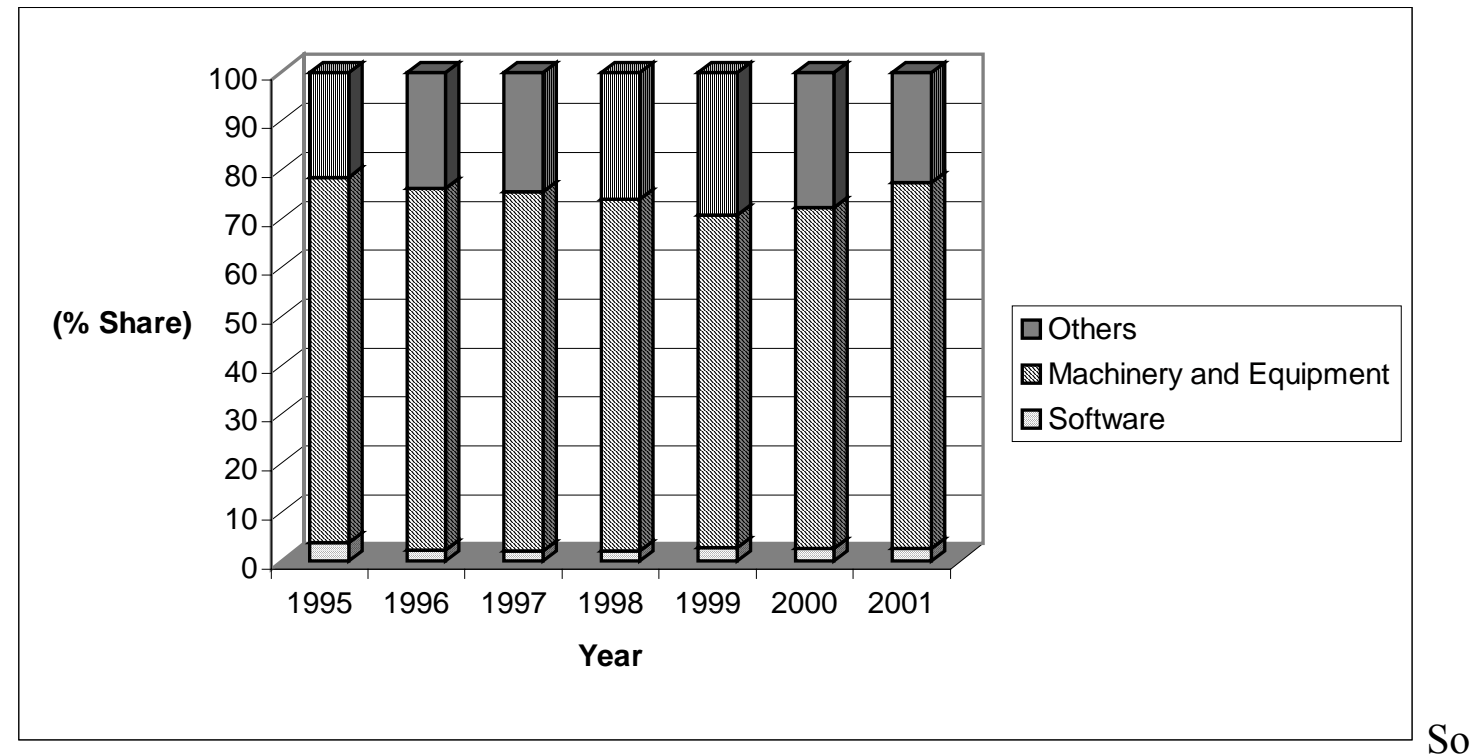

urce: Autor's calculation by using TURKSTAT data

a) The other types of investments are transportation vehicles; building construction; improvement of land and other construction; land; official materials which are fixtures and equipment; original film, advertisement films, programming of Radio and TV

In Figure 3.4, the details of fixed capital investments in private manufacturing industries are shown. As it is seen, in total investments, there is almost no share of computer and software. In the examined period, it has come to the maximum share in 1995 as $3.7 \%$. On the other hand, machinery and equipment investments are the highest type of investments. They averagely constitute $72 \%$ of total investments. 
Figure 3.5: R\&D Expenditures in Turkish Private Manufacturing Industries (1992-2001)

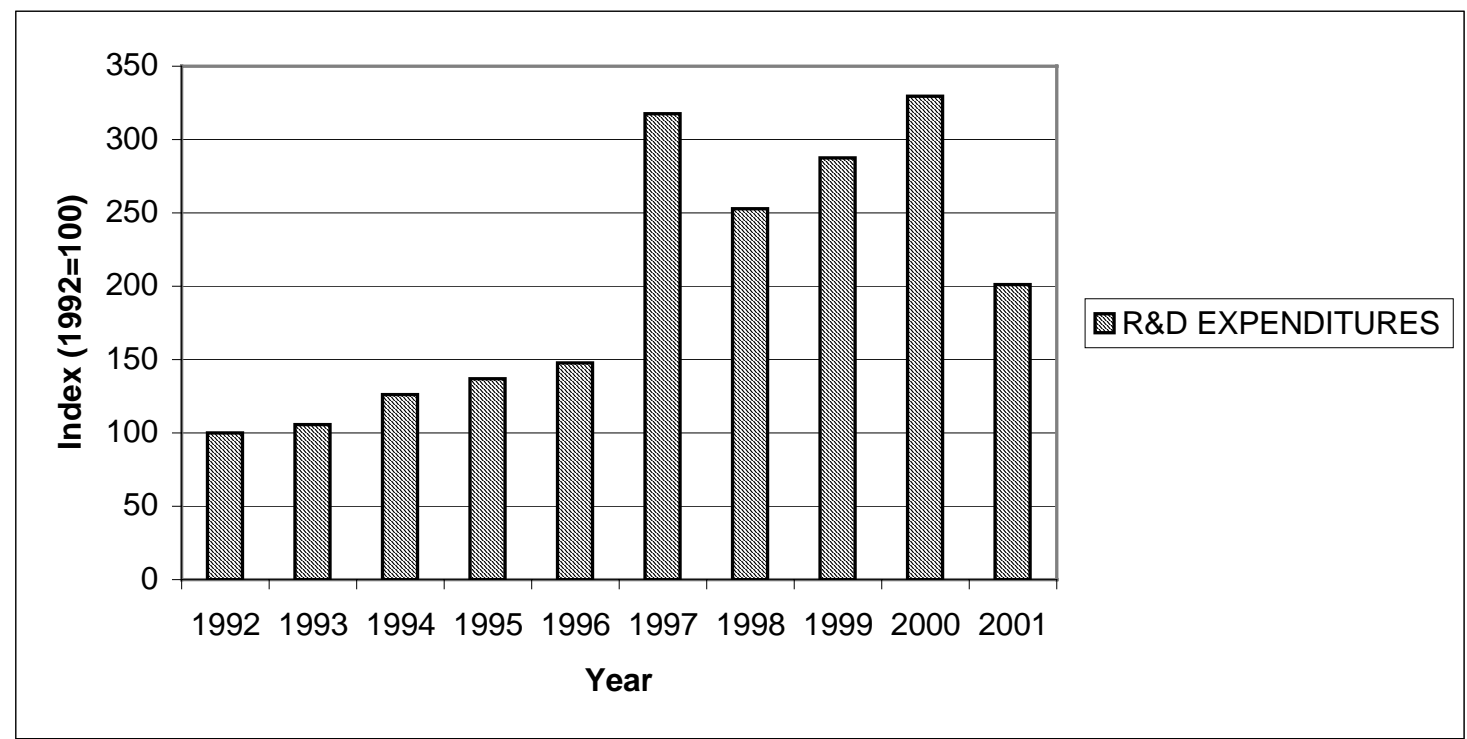

Source: Autor's calculation by using TURKSTAT data

Figure 3.5 depicts R\&D expenditures of Turkish private manufacturing industries. The expenditures increased despite of the crisis in 1994 and it has decreased in the crisis of 2001. In the period of ten years, R\&D expenditures increased two times. However, the best way to analyze $R \& D$ expenditures is to make an international comparison. In this respect, Figure 3.6 presents $R \& D$ shares (the share of $R \& D$ expenditures in total manufacturing production) of selected countries. 
Figure 3.6: R\&D Shares For Selected Countries (1992-2000) (a)

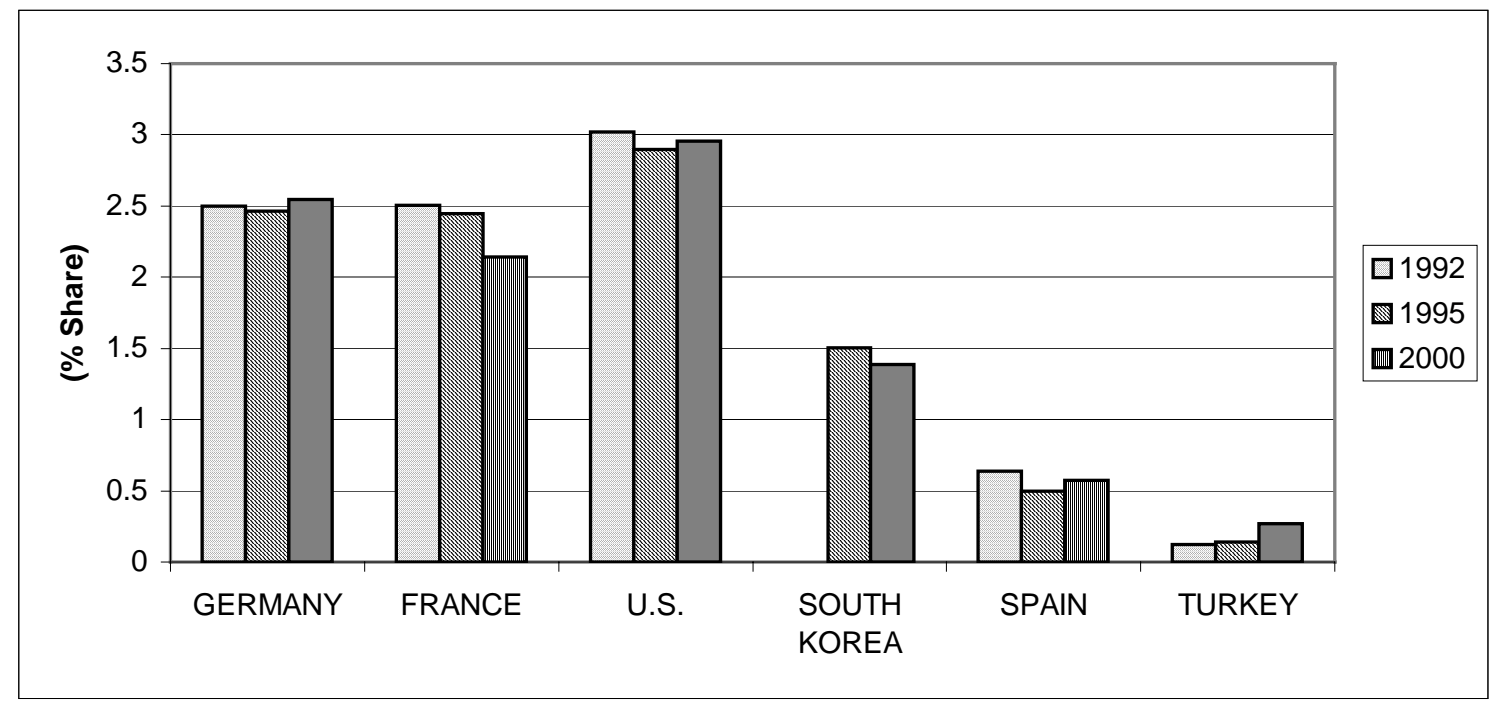

Source: TURKSTAT for Turkey; OECD.Stat, $<\mathrm{http}$ ://stat.oecd.org $>$ for the other countries

a) 1992 data of South Korea is unavailable

In Germany and France, R\&D share is nearly the same. However, the share has decreased during 1990s in France. For the all years, R\&D share of U.S. is the highest one. Although R\&D share has increased during 1900s, Turkey has the lowest proportion in these countries. When compared with Turkey and Spain, it is clear that South Korea is much more advanced in this area.

In the first part of the study, we pointed out that new technologies are related to skilled labor. Thus, technological progress is related with qualitative side of employment. Table 3.1 represents the number of skilled workers (high level technical personnel and medium level technical personnel) and the rate of skilled workers in Turkish Private Manufacturing Industries between the years of 1992 and $2001^{8}$. When we examine occupational data, the rate of skilled workers has a little place in total. The increase during the period is too low to care. The effects of crisis years on skilled labor

\footnotetext{
${ }^{8}$ See Appendix 3.1 for details of occupations.
} 
are different. In 1994, the number of skilled labor decreased 18\%. However, in 2001, it increased 3\%. This may arise because of that 2001 crisis affected financial sector much more than manufacturing industries.

Table 3.1: Technical Workers and Technical Workers Ratio in Total Workers in Turkish Private Manufacturing Industries (1992-2001)

\begin{tabular}{|c|c|c|}
\hline Year & Technical Workers & Technical Workers Ratio \\
\hline 1992 & 38029 & 5.19 \\
\hline 1993 & 47850 & 4.74 \\
\hline 1994 & 38872 & 5.27 \\
\hline 1995 & 38651 & 5.18 \\
\hline 1996 & 47743 & 5.20 \\
\hline 1997 & 51120 & 4.92 \\
\hline 1998 & 53451 & 5.28 \\
\hline 1999 & 51339 & 5.42 \\
\hline 2000 & 54025 & 5.75 \\
\hline 2001 & 56016 & \\
\hline
\end{tabular}

Source: Autor's calculation by using TURKSTAT data

Consequently, despite of the meager share of the manufacturing industries in total fixed capital investments, it has had an improvement in 1980s and 1990s. Yet, weakness of technological indicators complicates to correlate it with technological progress. 


\subsection{Sectoral Analysis of Turkish Private Manufacturing}

\section{Industries}

In this part, manufacturing industries are analyzed by focusing its sub-sectors. In this respect, we use two methods. Firstly, by using ISIC Rev. 3 classification system, we decompose the manufacturing industries as; high technology, medium-high technology, medium-low technology and low technology groups ${ }^{9}$. Secondly, the manufacturing industries are decomposed as ICT-producing, ICT-using and less intensive-ICT using industries ${ }^{10}$.

\subsubsection{R\&D Based Analysis}

In Figure 3.7, we demonstrate the share of firm numbers in private manufacturing industries. According to the figure, the high technology industries have a quite little share. The firm share of high technology industries can not exceed $3 \%$. On the other hand, low technology industries' share is higher than half of the private manufacturing firms.

\footnotetext{
${ }^{9}$ OECD, 2005. This decomposition is based on R\&D expenditure and output of twelve developed OECD countries. See appendix 3.2 and 3.3 for details of the classification system and decomposition.

${ }^{10}$ Van Ark et al., 2003. This decomposition is based on ICTs characteristics of industries. See appendix 3.4 for details.
} 
Figure 3.7: Firm Shares According to R\&D Levels (1992-2001)

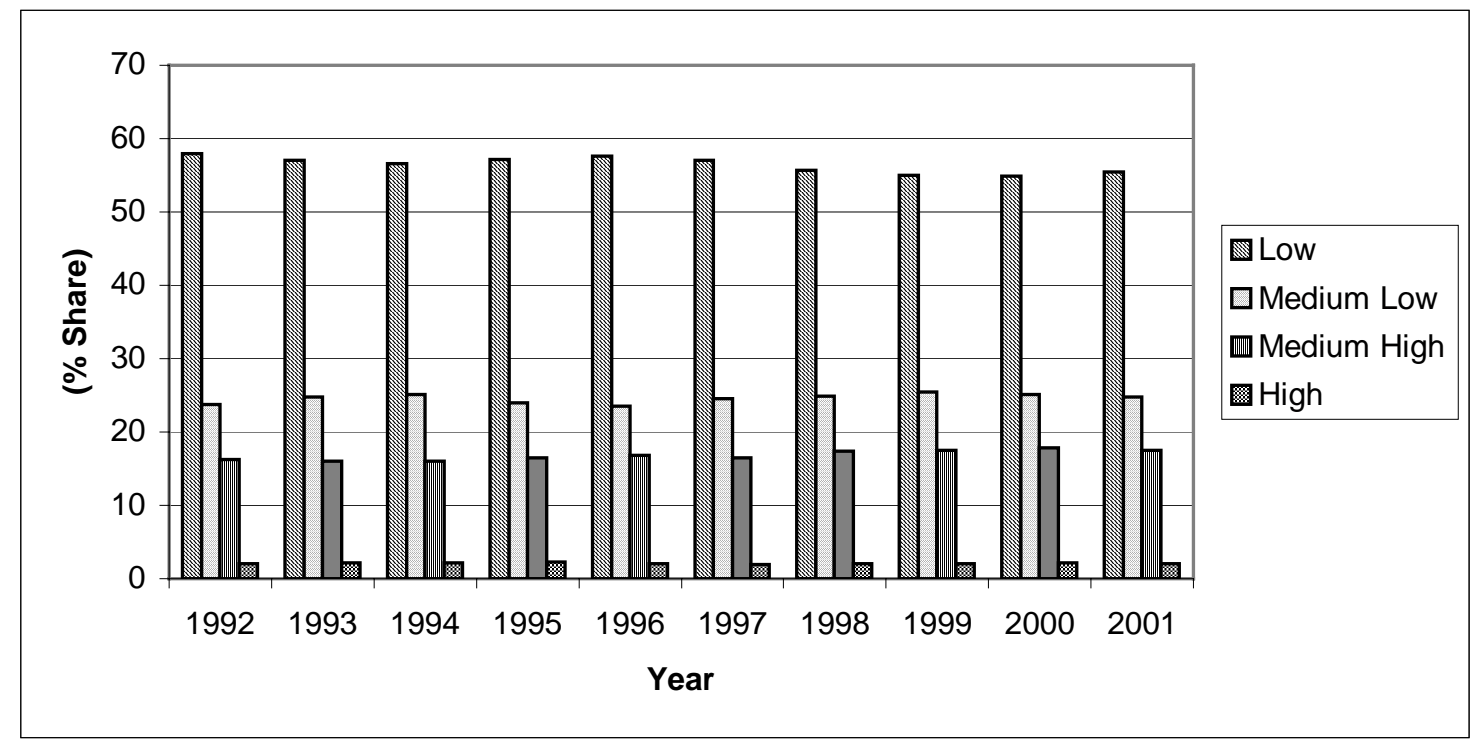

Source: Autor's calculation by using TURKSTAT data

The four sub-industries' shares of production in private manufacturing industries are represented in Figure 3.8. According to the figure, the share of low technology industries has increased from 1992 to 2001 and it is equal to $45 \%$ at the end of 2001 . However, the share of high technology industries is the lowest one across the group. Its highest share is equal to $6.8 \%$ in 2001 . Moreover, medium high and medium low technology industries have relatively stable production levels. 
Figure 3.8: Production Shares According to R\&D Levels (1992-2001)

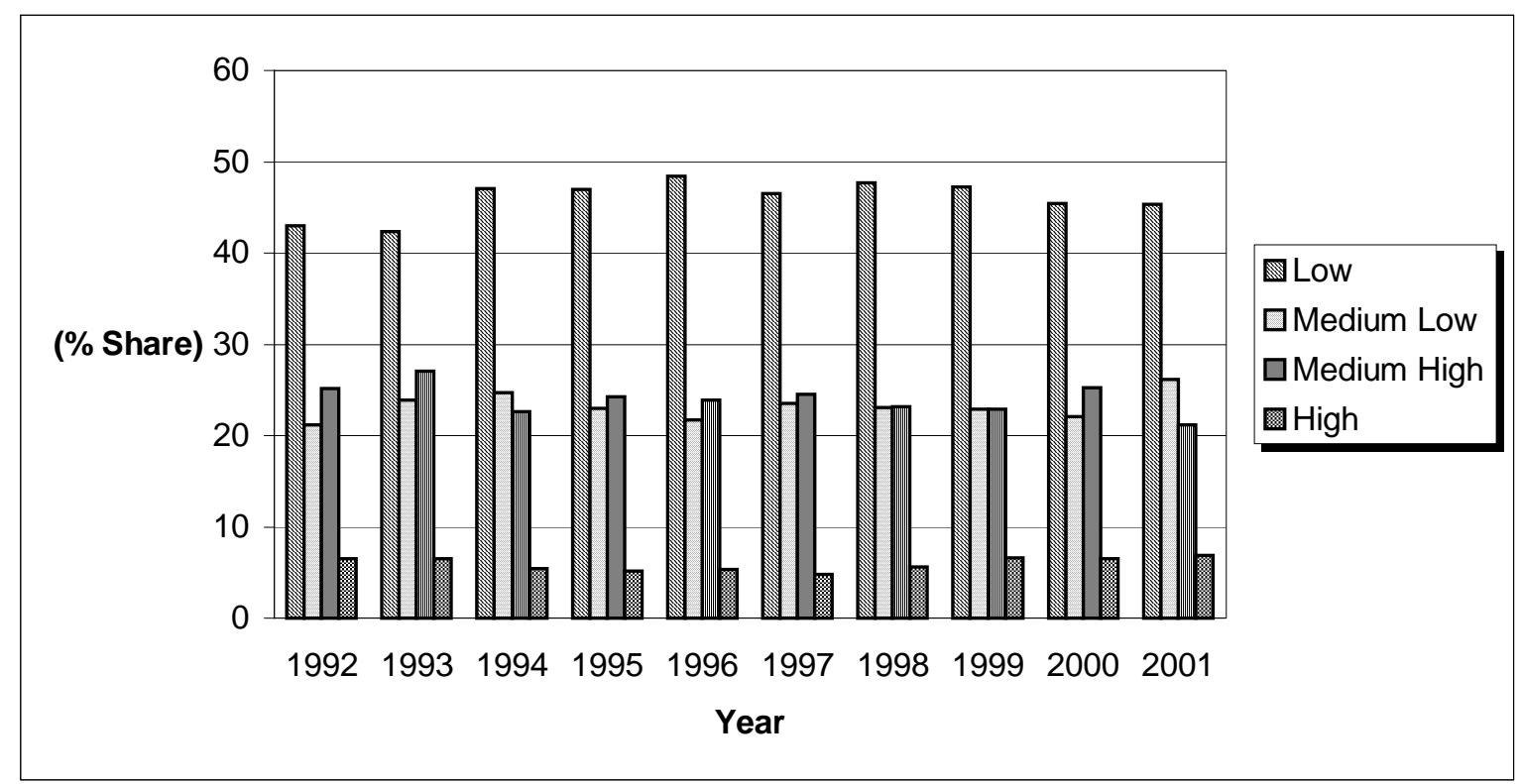

Source: Autor's calculation by using TURKSTAT data

Figure 3.9 demonstrates the employment shares of four sub-industries in private manufacturing industries. From the Figure 3.7, we know that the firm share of low technology industries are above 50\%. Similarly, the employment share of low technology sector exceeds $50 \%$. In addition to this, high technology industries have the lowest employment share across the four sub-industries. A remarkable point is that, in 2001 crisis, both the low technology industries and high technology industries increased their employment share. 
Figure 3.9: Employment Shares According to R\&D Levels (1992-2001)

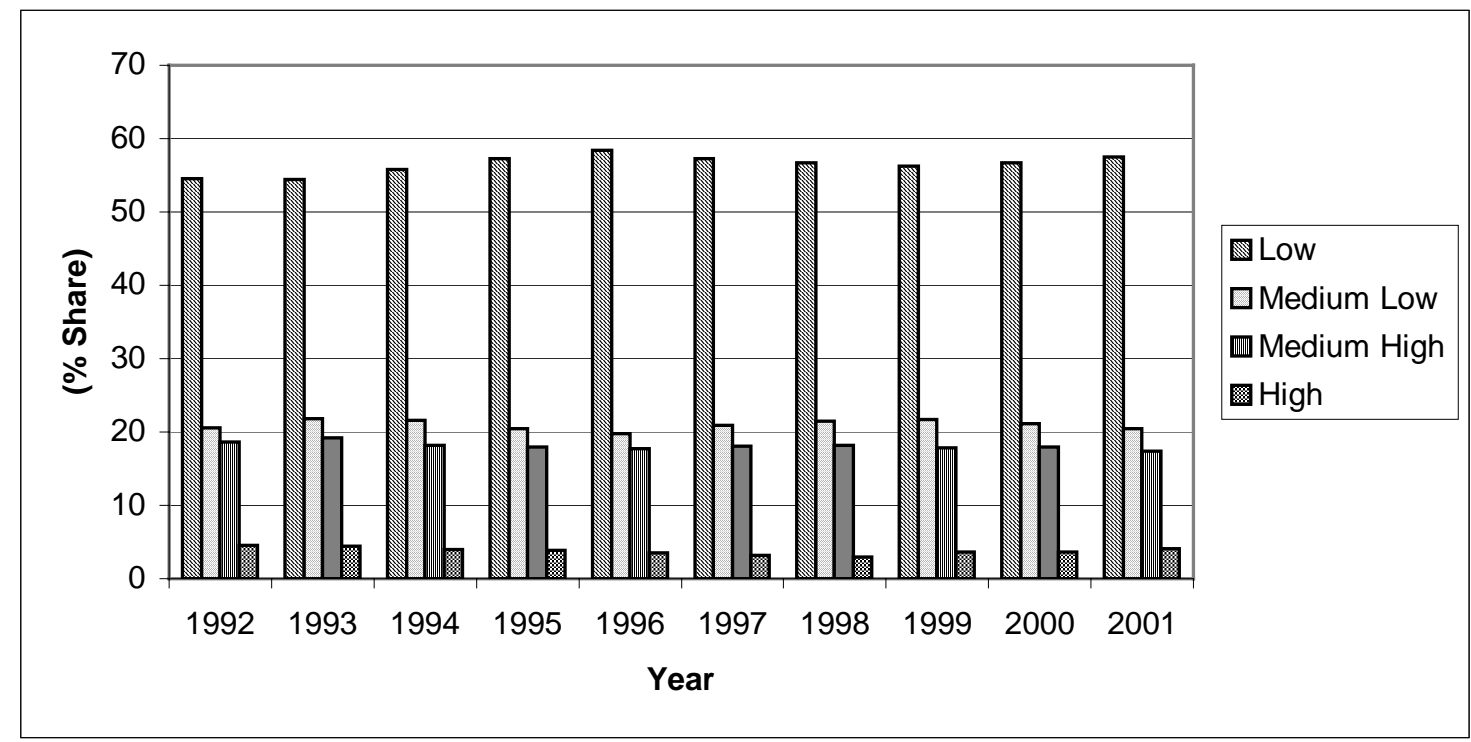

Source: Autor's calculation by using TURKSTAT data

Since we make an R\&D based classification, we want to analyze the R\&D expenditures of the four sub-industries. Figure 3.10 presents the average R\&D expenditures of the sub-industries. According to the figure, the sub-industries that make the highest R\&D expenditures are medium high and medium low technology industries. Total R\&D expenditures of these industries are nearly equal to $60 \%$. Although, the share of high technology industries is higher than low technology industries, it is not a considerable difference and, it is lower than the shares of medium high and medium low technology industries. 


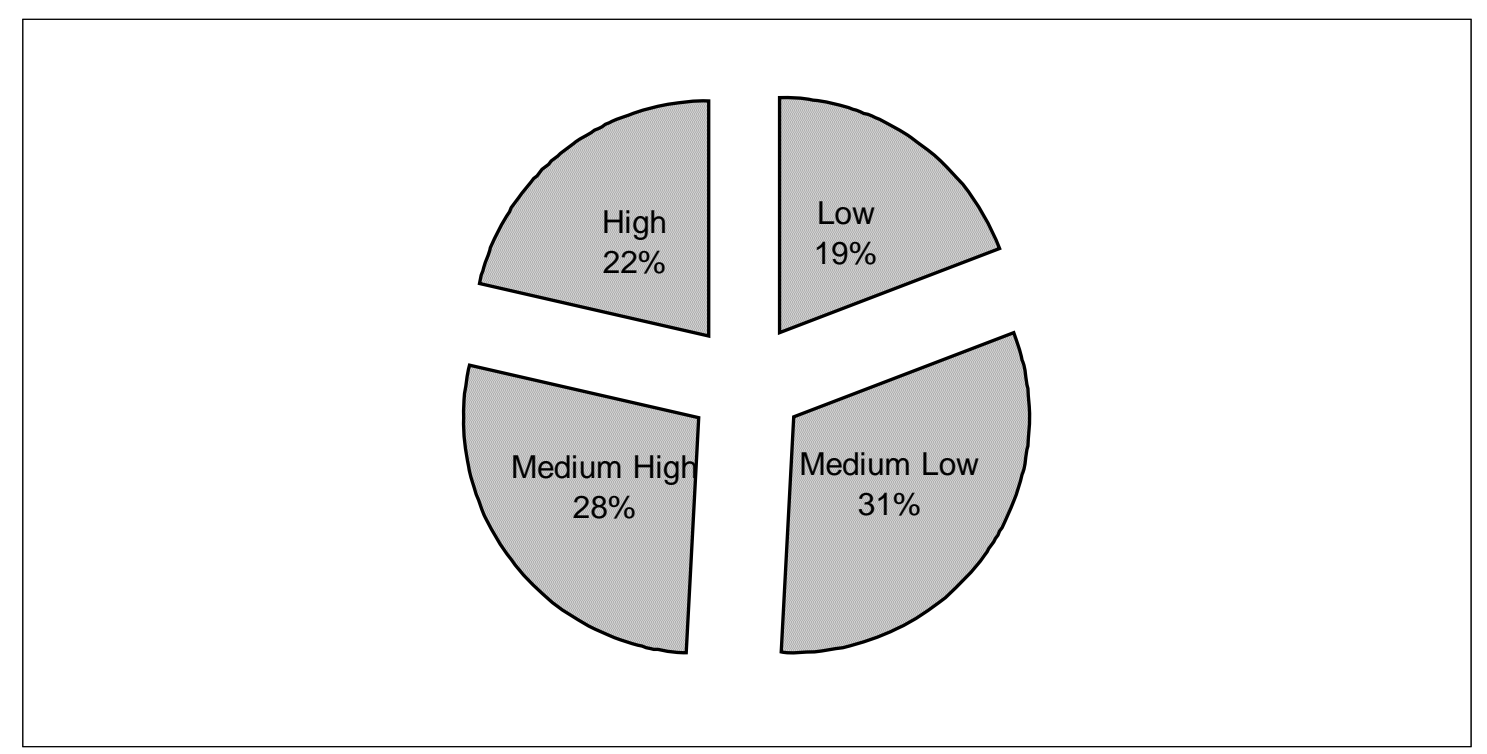

Source: Autor's calculation by using TURKSTAT data

As another technology indicator, computer and software investments can be analyzed. In Figure 3.11, we demonstrate the average investments in computer and software of sub-industries. High technology industries have the lowest proportion with only $9 \%$. According to the figure, between 1995 and 2001 period, averagely the highest share of computer and software investment is equal to $40 \%$ and belongs to low technology industries. 
Figure 3.11: Average Investments in Computer and Software According to Technology Levels (1995-2001)

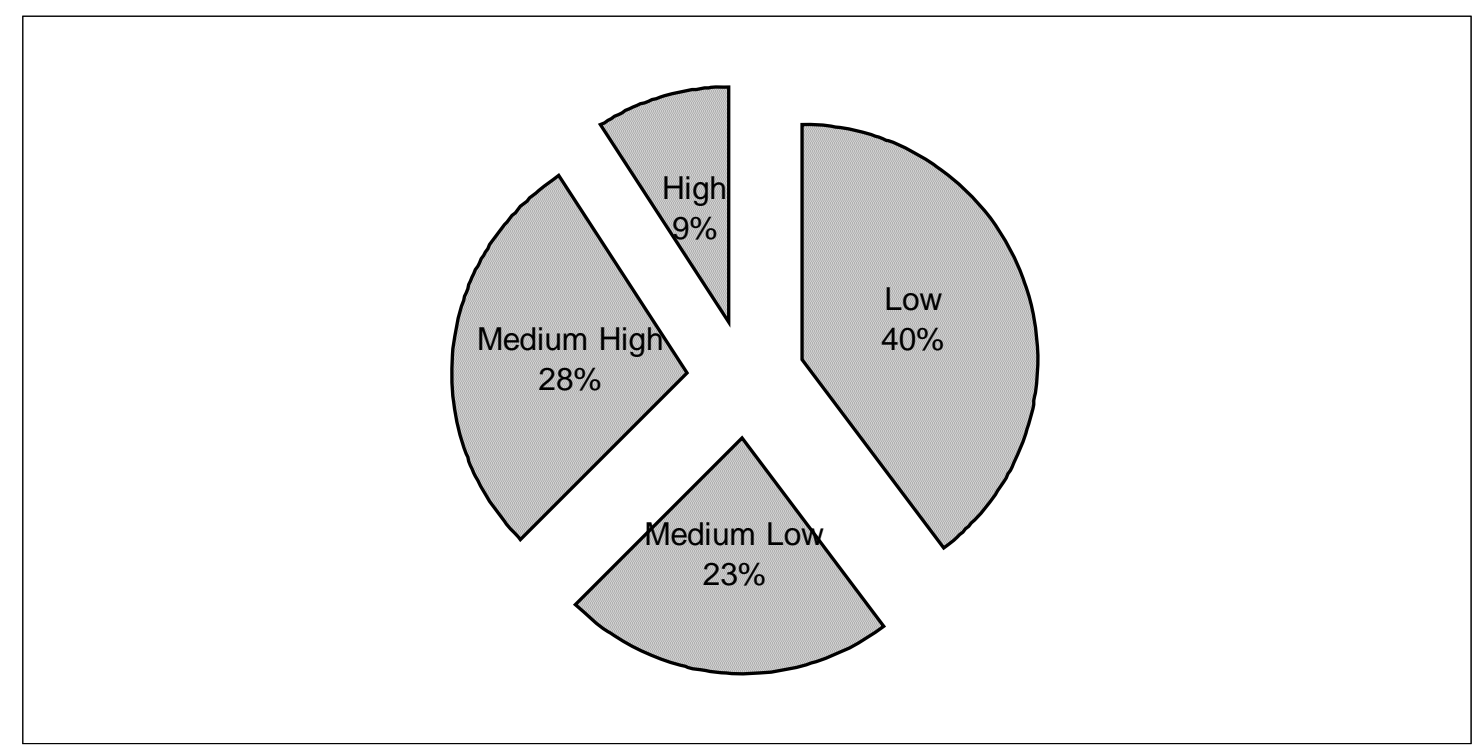

Source: Autor's calculation by using TURKSTAT data

Finally, we want to examine the skilled labor proportions of sub-industries. According to the Figure 3.12, low technology industries have the highest skilled labor share. The average share of these industries is equal to $42 \%$ in $1992-2001$ period. Beside, high technology industries have the lowest share. The average proportion of $6.9 \%$ is behind the shares of medium high and medium low technologies. 
Figure 3.12: Skilled Labor Shares According to R\&D Levels (1992-2001)

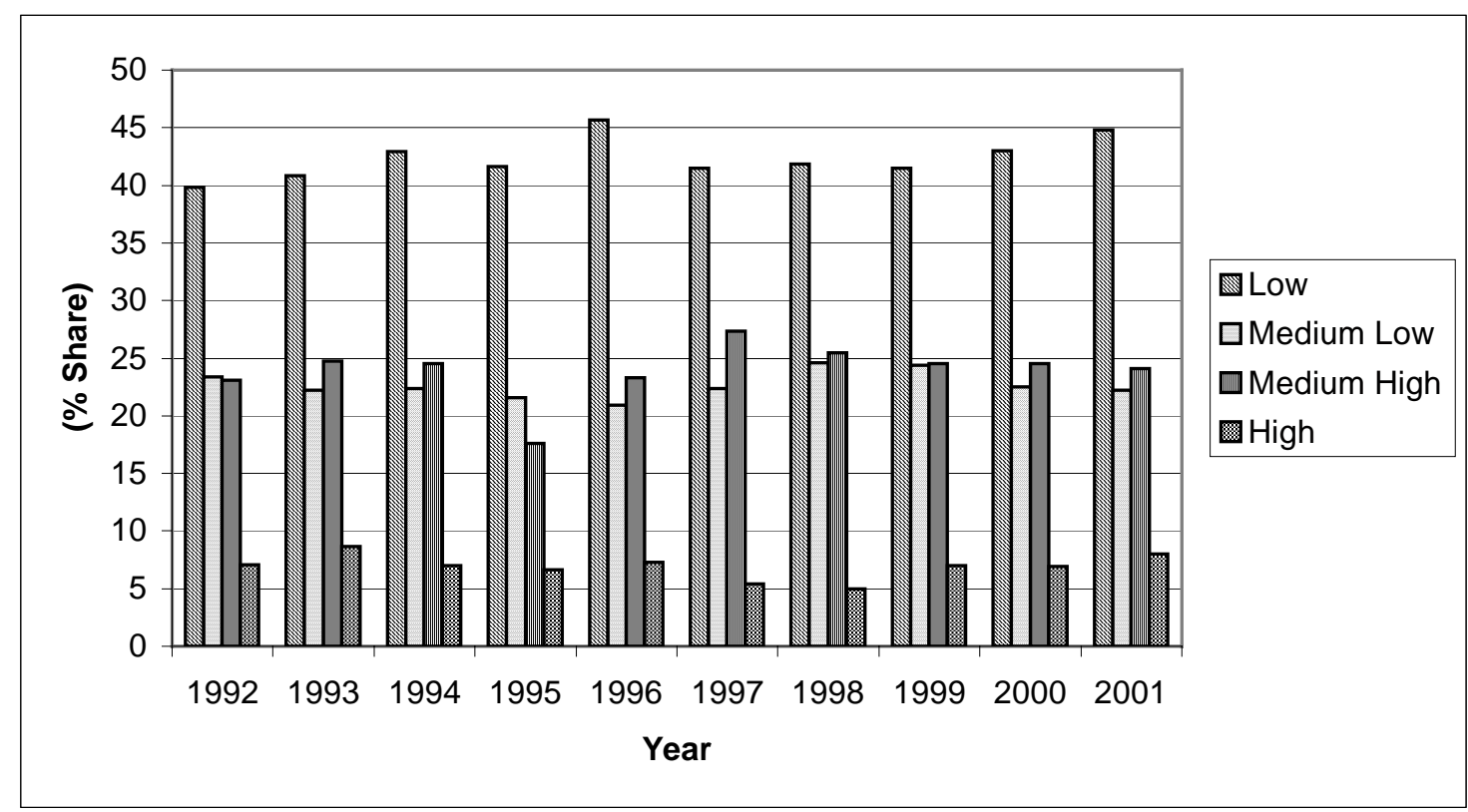

Source: Autor's calculation by using TURKSTAT data

\subsubsection{ICTs Based Analysis}

In this sub-section, manufacturing industries were decomposed as ICTproducing, ICT-using and less intensive-ICT using industries. We want to compare the three sectors with their number of firms, production, employment and technological features. Firm shares of sub-sectors are represented in Figure 3.13. 
Figure 3.13: Firm Shares According to ICTs Levels (1992-2001)

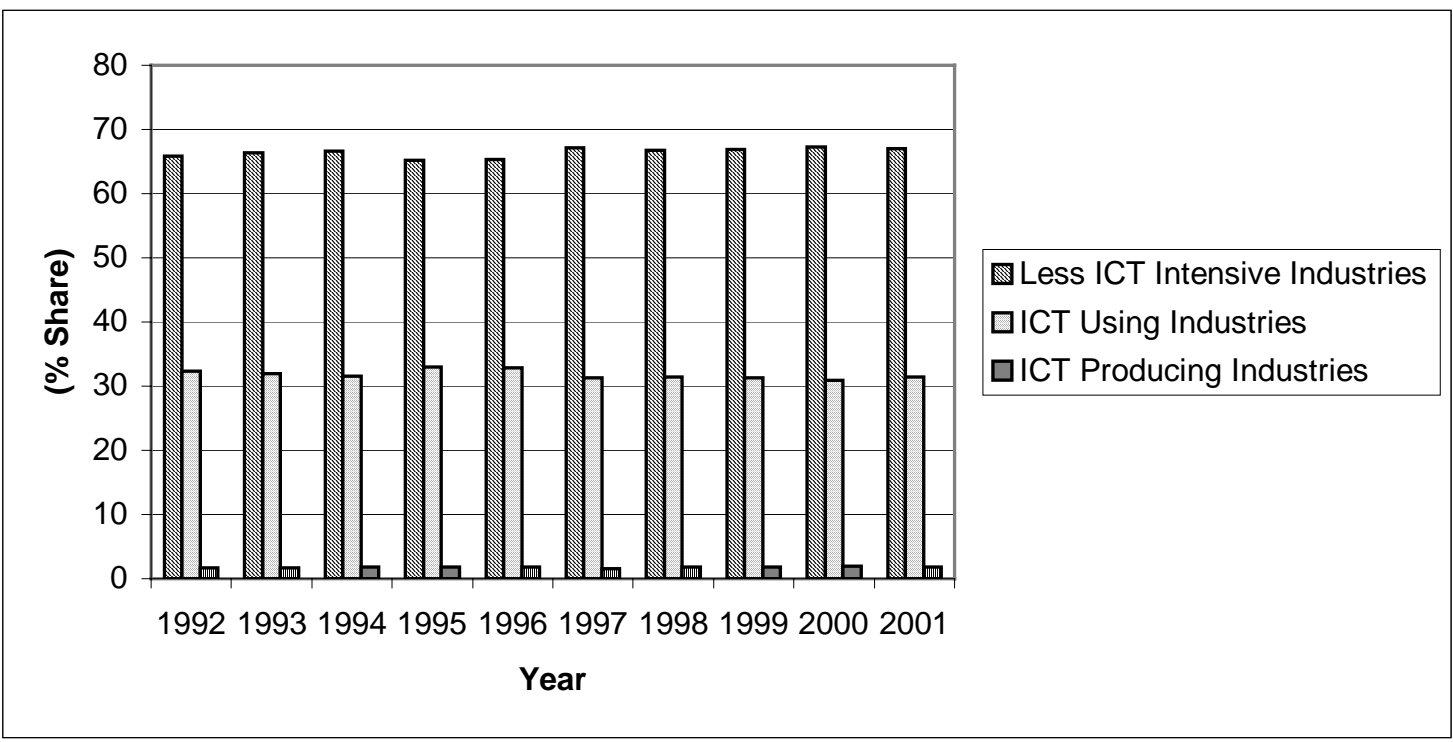

Source: Autor's calculation by using TURKSTAT data

In Turkish private manufacturing industries, ICT-producing industries have extremely little share of firms. The average of ten years is 1.7 . On the other hand, ICTusing industries are nearly equal to the half of the less intensive-ICT using industries. It is obvious that, less technology intensive firms dominate the private manufacturing industries just as in the R\&D based analysis. 
Figure: 3.14: Production Shares According to ICTs Levels

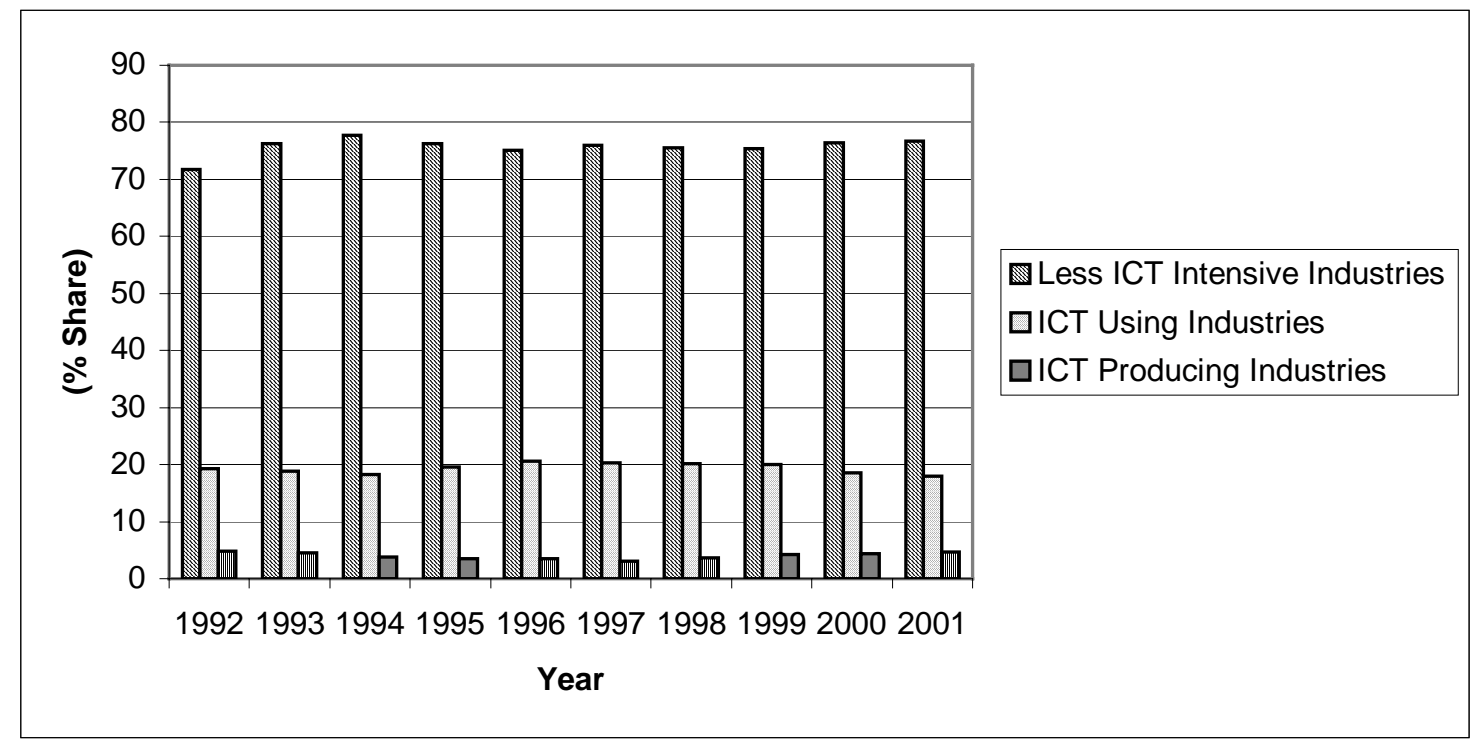

Source: Autor's calculation by using TURKSTAT data

In Figure 3.14, we demonstrate the production shares of the sub-sectors. The less intensive ICT using sectors have the biggest part. They produce averagely $75 \%$ of the total private manufacturing. The average shares of ICT-producing and ICT-using sectors are $4 \%$ and $19 \%$ respectively. 
Figure 3.15: Employment Shares According to ICTs Levels

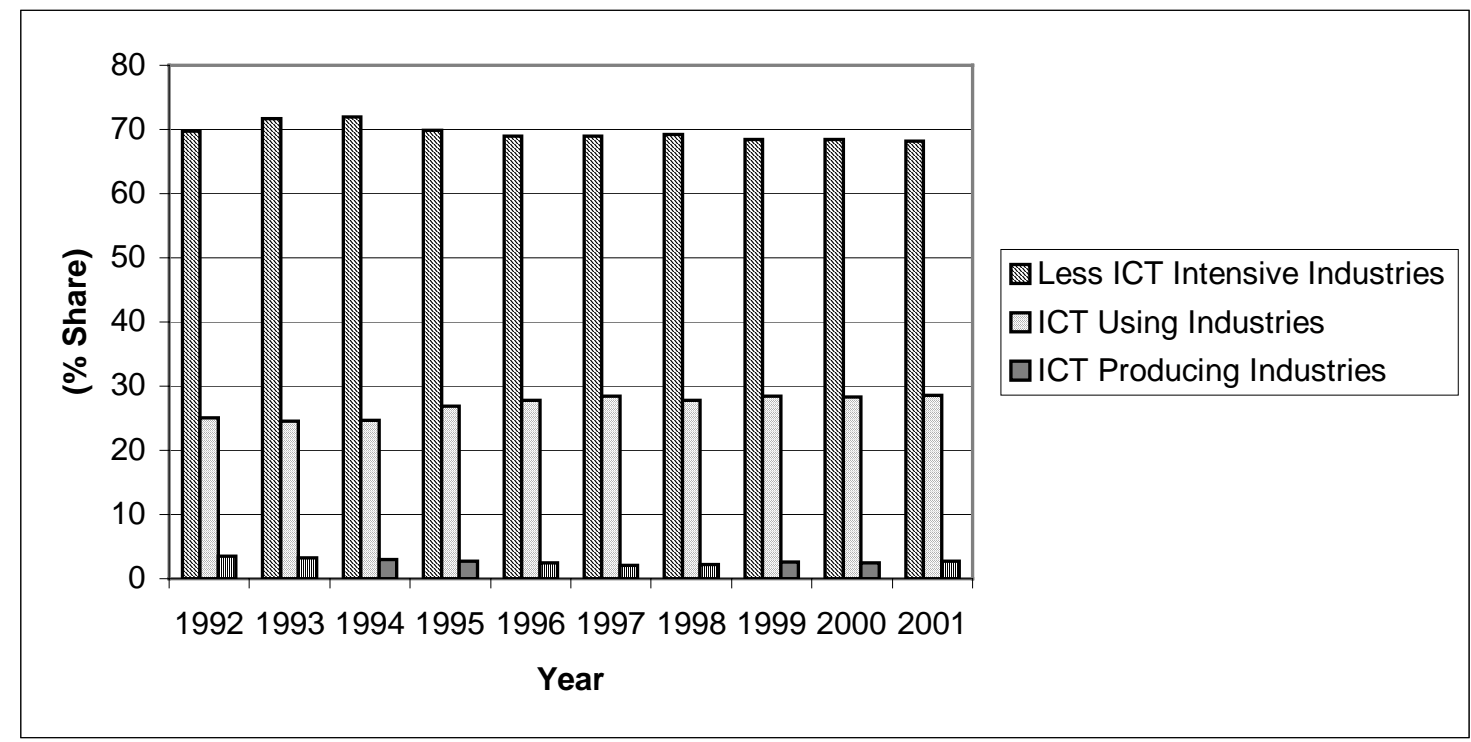

Source: Autor's calculation by using TURKSTAT data

Figure 3.15 depicts the employment shares of sub-sectors. Consistent with the above results, less intensive-ICT using industries employ averagely $69 \%$ of total workers. ICT-producing industries have the smallest part $2.7 \%$ and the share of ICTusing industries is $27 \%$. 
Figure 3.16 Average R\&D Expenditures According to ICTs Levels (1992-2001)

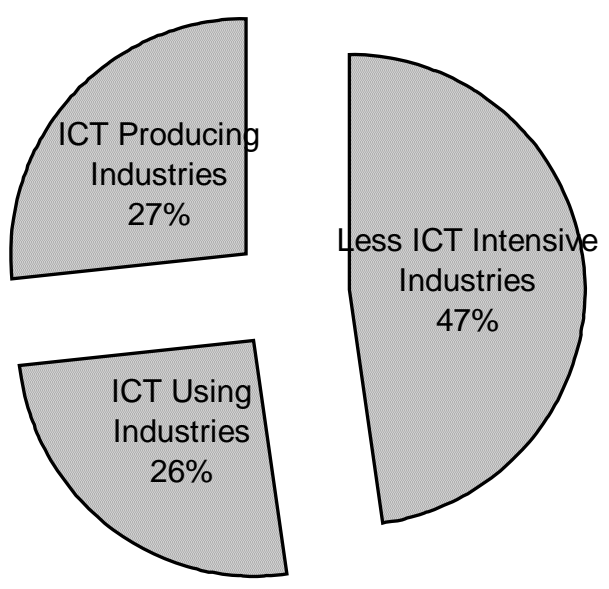

Source: Autor's calculation by using TURKSTAT data

In order to identify technology characteristics of industries, we demonstrate R\&D expenditures of sub-industries in Figure 3.16. Averagely, the biggest share belongs to less intensive ICT using industries. Moreover ICT-using and ICT-producing sectors have nearly the same share. 
Figure. 3.17 Average Investments in Computer and Software According to ICTs Levels (1995-2001)

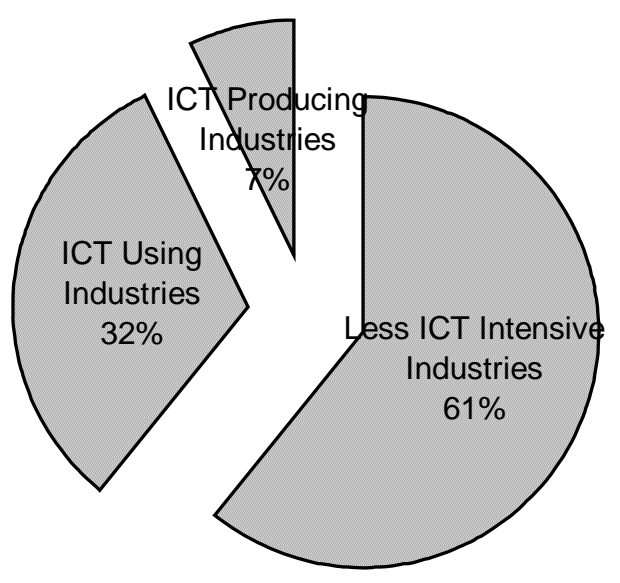

Source: Autor's calculation by using TURKSTAT data

Figure 3.17 represents the average investments in computer and software of subsectors between the years of 1995 and 2001. Less intensive ICT using industries have the biggest share also in this area. ICT-producing sectors are the ones that make the least computer and software investment in Turkish private manufacturing industries. 
Figure: 3.18: Skilled Labor Shares According to ICTs Levels

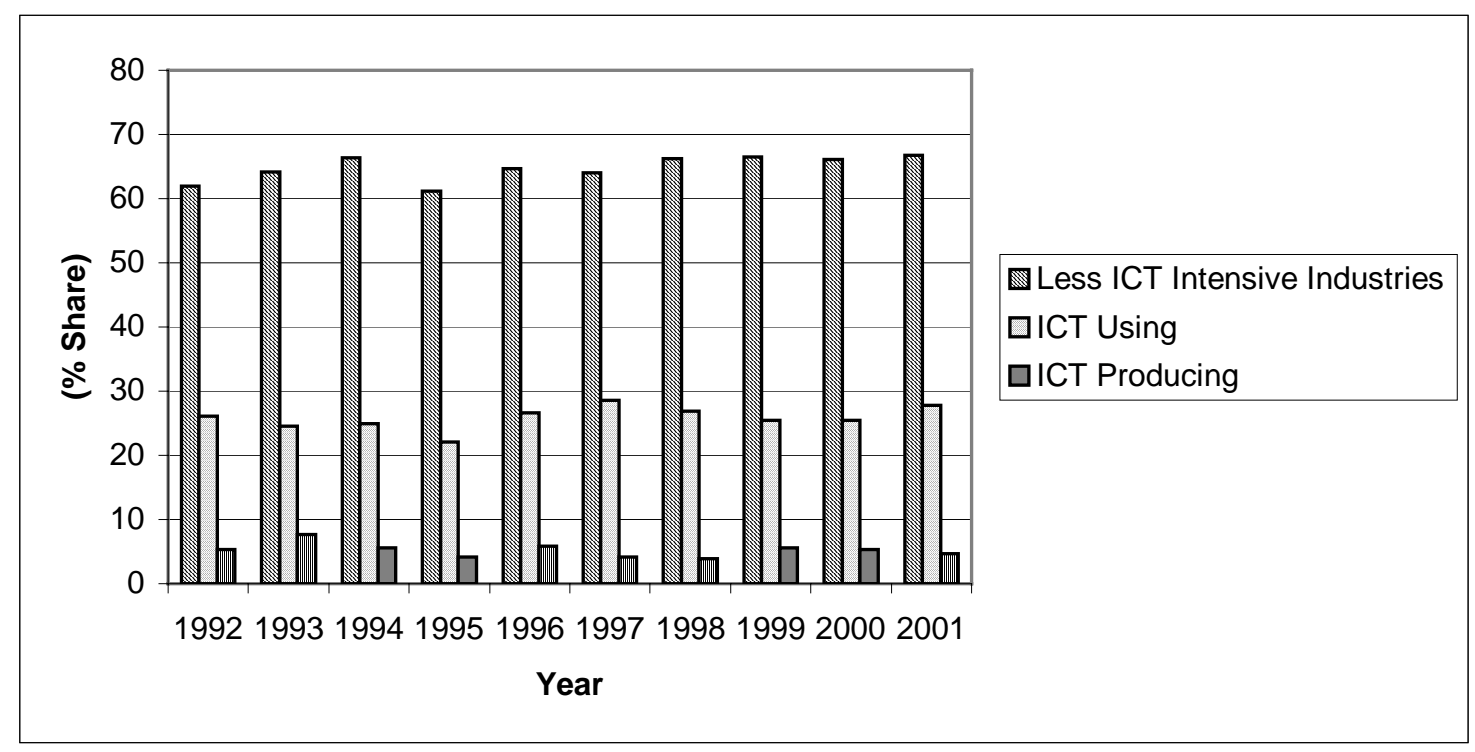

Source: Autor's calculation by using TURKSTAT data

Finally, we present skilled labor shares of sub-sectors in Figure 3.18. The skilled labor share of ICT-producing industries is averagely equal to $5 \%$. Whereas the biggest share is again belong to less intensive ICT using sectors as $64 \%$ and the average share of ICT using sectors is $25 \%$. Furthermore, it can be stated that the skilled labor share of less intensive ICT industries has increased during 1990s whereas the share of ICTproducing industries have decreased.

From the view of both two distinct classifications, these results expose clear evidences;

1. High technology industries (according to both R\&D based and ICTs based decompositions) have the least shares in terms of firm numbers, production, employment, skilled labor and, technology indicators. 
2. Turkish private manufacturing industries specialized in low technology industries. These industries have the biggest proportions in total.

3. Since low technology intensive industries have the biggest share, they have crucial importance for accelerating industrialization.

It should be noted that this analysis covers the years between 1992 and 2001 period and there are major developments after the 2001 crisis in Turkey. Doğruel and Doğruel (2008) states that in the post 2001 period, the production share of medium high technology industries has a considerable increase. In 2006, they have the biggest production share. Furthermore, the added value share of medium high technology industries has also increased. It nearly constitutes 30\% of total added value in 2004 .

\subsubsection{The Growing Importance of ICTs}

In consequences of the pervasive nature of the ICTs, it affects the economy as a whole. By quoting OECD (2003b) and O'Mahony and Van Ark (2004), OECD (2004b: 59-60) expresses the economic impacts of ICTs as follows:

1. ICT use has a positive impact on firm performance, productivity and wages, and is associated with plant expansion. However, the use of ICTs does not guarantee success; many firms improved performance were already experiencing better performance than the average firm. Moreover, the benefits of ICTs depend on the sector specific effects.

2. Computer networks may be particularly important, as they allow firms to outsource activities, to work more closely with customers and suppliers, and to 
better integrate activities throughout value and supply chains, with positive effects on productivity.

3. Impacts on services are also becoming more apparent, although not all sectors use the same technologies. For example, financial intermediation is the sector most likely to use network technologies. Impacts on distribution are also significant in some countries.

4. Skills are essential for effective ICTs use, and firm-level studies confirm that the combination improves productivity performance.

5. Organizational change is a key to benefiting from ICTs investment and is closely linked to the need for skilled human resources. The greatest benefits are realized when ICTs investment is combined with organizational change and change in business process and practices, organizational structures and human resource practices (greater voice in decision making, profit sharing mechanisms and new industrial relation practices), including such practices as total quality management, lean administration, flatter hierarchies and delegation of authority. Organizational change tends to be firm-specific, and returns to ICTs investment vary widely.

6. Adoption of advanced ICTs increases with the size of firms and plants. For example, large firms are more likely to use a combination of network technologies and broadband and to use the technologies to redesign and integrate information and communication flows within the firm, whereas small firms tend only to use the Internet marketing purposes.

7. The benefits of ICTs may only emerge over time, as firms need to adopt skills and organization. 
OECD (2004a: 186) points out that in all OECD economies the employment rates of low-educated people are much lower than those of the high-educated and the employment gap between high- and low-educated groups seems to be on the rise in practically all OECD countries. In addition to this, by quoting OECD (2003a), gives the example of between 1991 and 2001, the total employment rate increased by about 0.1 percentage points on an annual basis in the OECD area; during the same period, the employment rate of those with less than upper secondary education declined by about 0.3 percentage points each year. Although we do not have educational level data, we can use occupational level data in order to demonstrate the existence of demand for skilled labor in Turkey.

Figure 3.19: Skilled Labor and Skilled Labor Share in Turkish Private Manufacturing Industries (1992-2001)

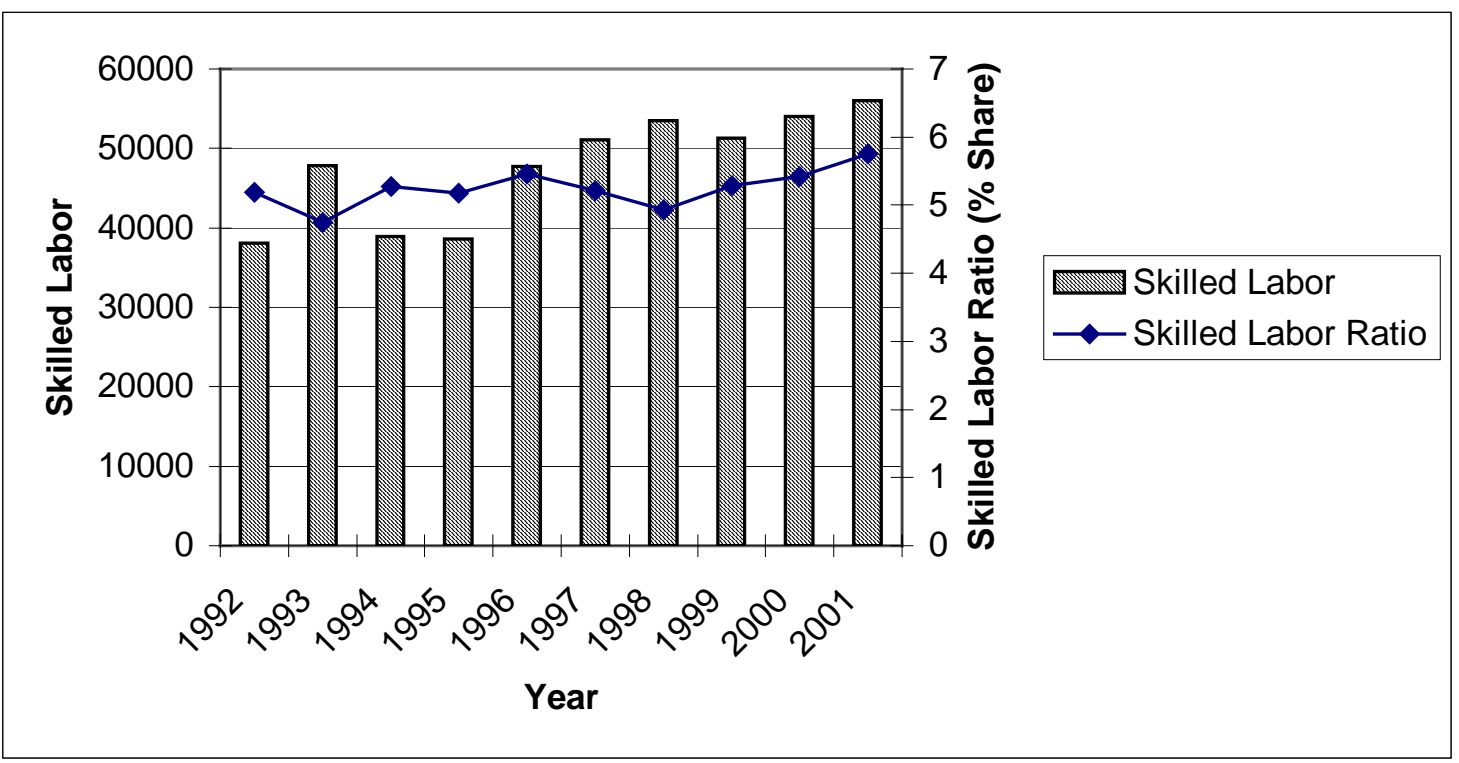

Source: Table 3.1

Figure 3.19 demonstrates the skilled labor and skilled labor ratio in Turkish private manufacturing industries. The skilled labor ratio is 5.1\% in 1992 and $5.7 \%$ in 2001. It is not a remarkable increase. Notwithstanding, skilled labor has rose 
substantially since 1992. It increased 32\% from 1992 to 2001. Can we make a connection between this upward tendency and technological progress? OECD (2004b: 218) states that the diffusion of ICTs have led to productivity gains and new employment opportunities, with new demands in terms of workers' skills.

The above-mentioned literature mostly states that the increasing demand for skilled labor is related with the increasing use of the new technologies, namely ICTs. As those studies mostly examine U.S, rather developed countries, we want to investigate this relationship in a developing country case, Turkey. In this respect, we want to examine the general acceptance of this stylized fact. 


\section{CHAPTER 4}

\section{EMPIRICAL ANALYSIS}

This section provides a brief overview of literature on technological progress. After defining various types of technological change we present the empirical results of our analysis.

\subsection{Technological Change}

First of all, what is technological progress? From the neoclassical perspective, the representative firm has perfect information concerning inputs and outputs and maximizes profits. At any time, there is a given level of technology, which determines the techniques available for production. Among the available techniques the firm will choose the one which, given existing prices minimizes total production cost (Coombs et al., 1987, p.25).

Let's define the conventional production function;

$$
Q=f(K, L)
$$


where $Q$ is output, $K$ capital and $L$ labor. In Figure 4.1, the isoquants represent the same level of output. Although firm produce the same level of output by using the techniques which minimizes total cost, $\mathrm{Q}_{2}$ uses less labor and capital. Hence technological change can be defined as a shift of the isoquant towards the origin.

\section{Figure 4.1: Technological Change and Production Functions}

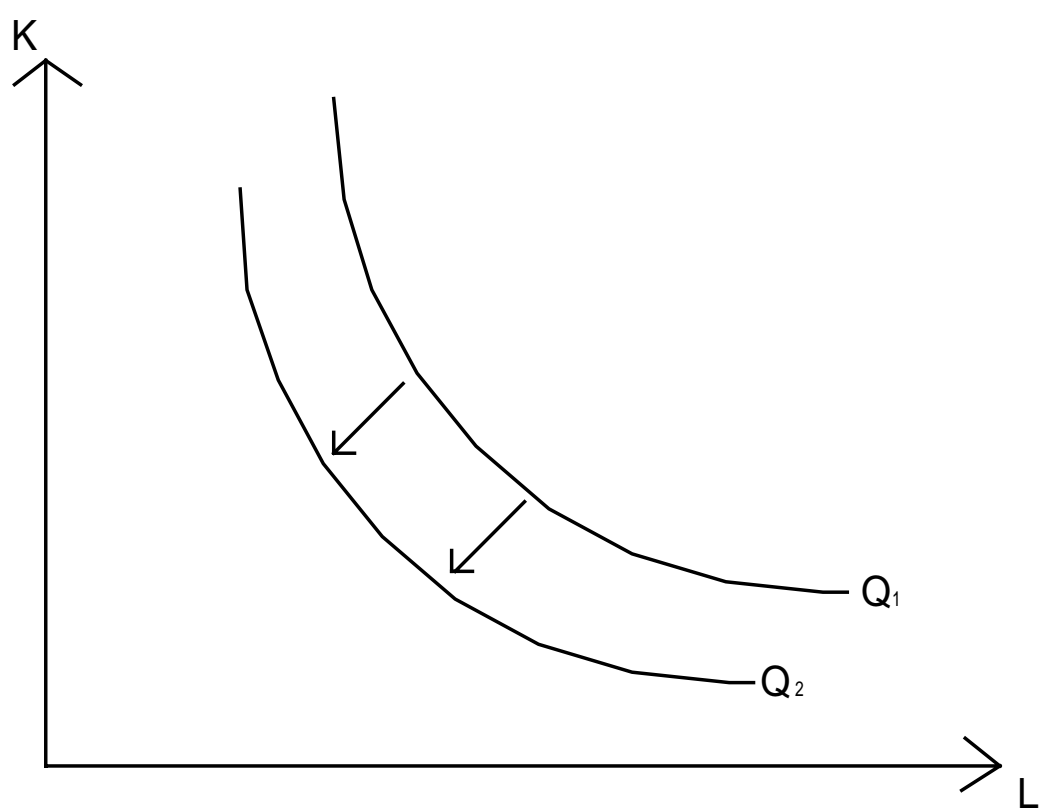

Source: Adapted from Taymaz (1996, p.192)

Before going further, let's define the bias of technological progress. "Inventions may allow producers to generate the same amount of output with either relatively less capital input or relatively less labor input, cases refer to as capital-saving or laborsaving technological progress respectively. Inventions that do not save relatively more of either input are called neutral or unbiased" (Barro and Sala-i Martin, 2004, p.52). There are different definitions of neutrality of technological progress. 
1. If we consider an economy developing such that the capital-output ratio remains constant, then "Harrod neutrality" exists if factor shares are not affected by technological change.

2. If we consider an economy developing such that the labor-output ratio is constant, then "Solow neutrality" exists if factor shares do not change with technological change.

3. If we consider an economy developing such that the capital-labor ratio is constant, then "Hicks neutrality" exists if factor shares do not change with technological change (Stoneman, 1983, p.5).

By adapting Hicks definition, Figure 4.2 represents the bias and neutrality of technological progress. If $\mathrm{Q}_{1}$ shifts to $\mathrm{Q}_{3}$, at constant factor prices firm uses proportionally more capital (labor saving technological change); if $\mathrm{Q}_{1}$ shifts to $\mathrm{Q}_{4}$, firm uses proportionally more labor (capital saving technological change); if $\mathrm{Q}_{1}$ shifts to $\mathrm{Q}_{2}$ firm uses the same combination of inputs as $\mathrm{Q}_{1}$ (Hicks neutral technological change). 


\section{Figure 4.2: Neutral and Biased Types of Technological Change}

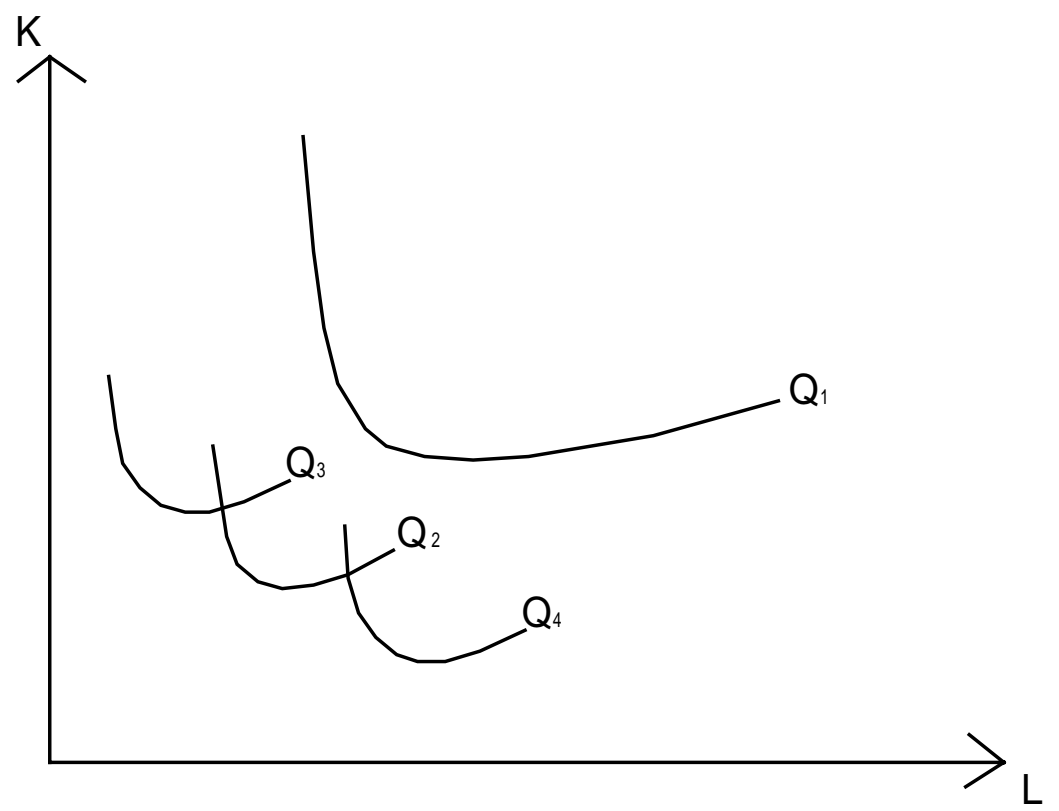

Source: Adapted from Coombs et al. (1987, p.27)

Now let's assume that there are only two types of inputs; skilled $\left(\mathrm{L}_{\mathrm{s}}\right)$ and unskilled $\left(\mathrm{L}_{\mathrm{u}}\right)$ labor who are imperfect substitutes. Each worker is paid according to its marginal productivity. In this case, technological change can be depicted in Figure 4.3. Under skill-biased technological change, the ratio of skilled to unskilled labor rises at the same relative wage, or the relative wage of skilled labor rises at the fixed factor ratio (Sakurai, 2001). The inward shift of the $\mathrm{Q}_{1}$ to $\mathrm{Q}_{2}$ represents technological change just as in Figure 4.1. If the new equilibrium is realized at point $\mathrm{C}$, technological change is skillbiased, the factor ratio $\left(L_{u} / L_{s}\right)$ declines from OA to OC at the same relative wage, or the relative wage $\left(W_{s} / W_{u}\right)$ rises at the fixed factor ratio. On the other hand, if technological change is Hicks neutral the new equilibrium is realized at point B. 
Figure 4.3: Skill Biased Technological Change

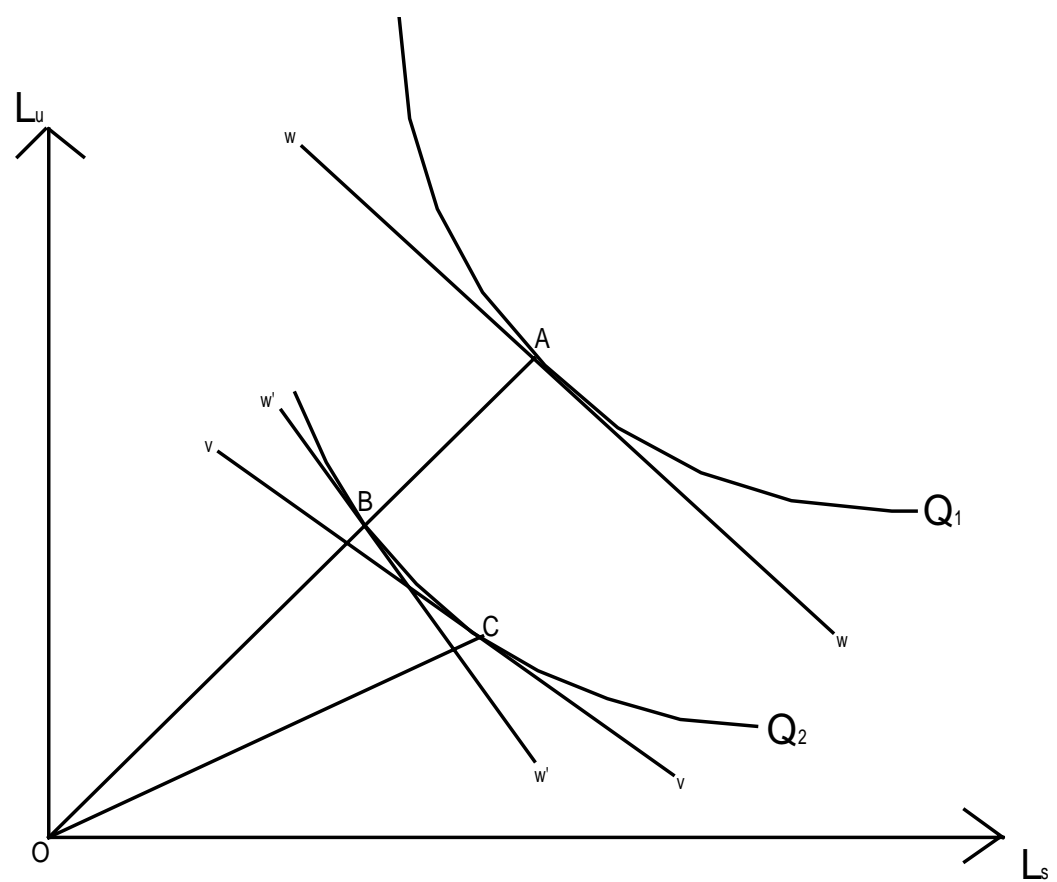

Source: Adapted from Sakurai (2001)

\subsection{Literature Survey}

Moving from the stylized facts, researchers investigated Skill Biased Technological Change ${ }^{11}$ (SBTC) hypothesis. The results of studies are summarized below.

Berman et al. (1994) examines U.S. manufacturing industries between 1959 and 1987 and find a positive relation between technological progress (R\&D expenditures and computer investments) and nonproduction share of wagebill and employment.

${ }^{11}$ SBTC refers to any introduction of a new technology, change in production methods, or change in the organization of work that increases the demand for more-skilled labor (e.g., college graduates) relative to less-skilled labor (e.g., non-college workers) at fixed relative wages (Katz, L., F., 2000, p.1) 
Autor et al. (1998) studies the U.S. labor market from 1940 to 1995 and states that rising demand for skilled labor despite increasing wage bill of this group supports the SBTC hypothesis. The relative demand for more-skilled workers grew more rapidly on average from 1970 to 1995 than during the 1940-1970. Moreover, educational and occupational skill upgrading occurred more rapidly in industries with greater computer utilization.

Bartel and Lichtenberg (1987) investigates U.S. manufacturing industries between 1960s and 1980s and states that the relative demand for educated workers declines as the capital stock -which embodies technology- ages. Hence highly educated workers have a comparative advantage with respect to the adjustment to and implementation of new technologies.

Doms, et al. (1997) differs from the other studies. This study states that the results of the regressions are different according to the type of the technology. It is found that the adoption of factory automation technologies (CIM systems tools such as $\mathrm{CAD}, \mathrm{CAM}$ and $\mathrm{CNC}$ ) is uncorrelated with changes in the nonproduction labor share, while computer investment is strongly correlated with the changes in the share of nonproduction workers in the plant. This should not be too surprising since computers are a primary tool of overhead labor, while many of the factory automation technologies are primarily used by production workers. Furthermore, when automation technologies used, it is clear that, plants that use more advanced production technologies employ production workers who earn higher wages. 
Bartel et al. (2003) examines valve manufacturing industries for the years between 1980 and 2002. They state that, due to automation -increasing use of CAD, CAM- demand for less skilled operators declined. Employers wish to hire skilled machinists since $\mathrm{CNC}$ machines have broader range of machining activities; newer technologies require employees to undertake more problem-solving activity and more computer skills such as programming. Moreover, they show that, new information technology is correlated with the use of new human resources management practices such as problem-solving teams and incentive pay.

Machin and Van Reenen (1998) investigates SBTC hypothesis in seven developed countries (U.S., United Kingdom, France, Germany, Denmark, Sweden and Japan). The results provide evidence that skill-biased technological change is an international phenomenon that has a clear effect of increasing the relative demand for skilled workers.

Vivarelli (2002) investigates the SBTC hypothesis in Italian manufacturing industries between 1991 and 1997. He concludes that organizational change is the main factor for the upskilling of the labor force. Whereas technological change seems to play a negligible role.

Betts (1997) analyzes Canadian manufacturing industries from 1962 to 1986 and found positive relation between technological change and skill upgrading. 
Gera et al. (2001) examines both service and manufacturing sectors of Canada from 1981 to 2004 and found that skill upgrading is related with different types of technology such as the stock of patents and the age of capital stock.

Sakurai (2001) investigates Japanese manufacturing industries in 1980s. By using computer investments as a technology variable, the author finds that technological progress contributed substantially to the increase in the wage-bill share of nonproduction workers.

Kızılırmak (2003), studies SBTC hypothesis for Turkish private manufacturing industries for 1988-1998 period. This study employs total factor productivity (TFP) as a technology variable instead of using $R \& D$ intensity or investments in computer and software. The results state that, technological change had no effect on the skilled labor demand in Turkish private manufacturing industries in the first half of 1990s, however, there are indications that it had a positive effect in the second half of it.

\subsection{Data and Estimation Results}

\subsubsection{Data}

We use ISIC Rev. 3 four digit Turkish private manufacturing industries data which were obtained from TSI. We prefer to examine private manufacturing industries since the public employment policy may not be rationally conducted. Our data cover the 1992-2001 period and consist of 107 industries after excluding several industries due to lack of data. 


\subsubsection{Model Specification and Empirical Results}

We use translog cost function as it is widely used in the literature. This function was originally developed by Kmenta (1967) and empirically tested by Christensen, Jorgensen and Lau (1973) and Christensen and Greene (1976). Assume that capital is a "quasi fixed" input and cost is determined by variable input prices (skilled and unskilled labor), capital stock and output. The translog cost function can be written as ${ }^{12}$;

$[2]$

$\ln (T C)=\alpha_{0}+\alpha_{Y} \ln Y+\frac{1}{2} \gamma_{Y Y}(\ln Y)^{2}+\sum_{i} \alpha_{i} \ln P_{i}+\frac{1}{2} \sum_{i} \sum_{j} \gamma_{i j} \ln P_{i} \ln P_{j}+\sum_{i} \gamma_{Y i} \ln Y \ln P_{i}$

where $\gamma_{i j}=\gamma_{j i}, T C$ is total cost, $Y$ is output and $P_{i}$ 's are the prices of the factor inputs. In order to correspond to a well-behaved production function, a cost function must be homogeneous of degree one in prices; that is, for a fixed level of output, total cost must increase proportionally when all prices increase proportionally. This implies the following relationships among the parameters;

[3] $\quad \sum_{i} \alpha_{i}=1$,

[4] $\quad \sum_{i} \gamma_{Y i}=0$,

[5] $\quad \sum_{i} \gamma_{i j}=\sum_{j} \gamma_{i j}=\sum_{i} \sum_{j} \gamma_{i j}=0$.

${ }^{12}$ The following derivation is based on Christensen and Greene (1976). 
Applying Shephard's lemma we obtain the following equation,

[6]

$$
S_{i}=\alpha_{i}+\gamma_{Y i} \ln Y+\sum_{j} \gamma_{i j} \ln P_{j}
$$

where $S_{i}$ indicates the cost share of the $i$ th-factor input. The equation we will estimate can be written as;

$$
S_{i t}=\delta_{i t}+\beta_{1} \ln Y_{i t}+\beta_{2} \ln K_{i t}+\beta_{3} \operatorname{Tech}_{i t}+\beta_{4} \ln \left(W_{i t}^{s} / W_{i t}^{u}\right)+u_{i t},
$$

where $i$ and $t$ index industry and year respectively. $S_{i}$ is the share of skilled workers in total workers, $Y$ is real output ${ }^{13}, K$ is the capital stock, tech represents technology and $W^{s}$ and $W^{u}$ represent skilled and unskilled workers' wages respectively.

Following the literature we exclude relative wage term, as it is not plausible to threat it exogenous ${ }^{14}$ and include the openness term in order to obtain the effects of international trade on the labor composition. The equation, which we finally estimate is the following;

\footnotetext{
${ }^{13}$ We calculated real values by using TSI price index $(1994=100)$.

${ }^{14}$ See Berman et al. (1994).
} 


$$
S_{i t}=\delta+\beta_{1} \ln Y_{i t}+\beta_{2} \ln K_{i t}+\beta_{3} \text { Tech }_{i t}+\beta_{4} \text { Openness }_{i t}+\varepsilon_{i t}
$$

The output term in the equation represents the size effect. That means if $\beta_{1}$ is positive, large firms employ more skilled labor. However, as we use industry level data, the real output is divided by the number of the firms exist in the industry in order to get the size effect.

Capital stock is calculated by performing perpetual inventory method ${ }^{15}$. The capital-skill complementarity requires positive $\beta_{2}$. The positive $\beta_{2}$ means that new capital is complemented by more skilled labor since it requires some additional skills.

We have two kinds of technology measures; R\&D intensity (R\&D expenditures over sales revenue) and the ICTs intensity (share of investments in computer and software in output). These two different types of technology variables let us examine different kinds of technology skill relation. By using R\&D expenditures and investments in computer and software, we assume that more technologically advanced industries make more $R \& D$ expenditures and more computer investments. We expect positive $\beta_{3}$ to support skill-biased technological change hypothesis in Turkey.

The international trade effect can be obtained either by using export intensity (export over output) or import intensity (import over output) of an industry. Although two variables are used in different studies, we think that export variable is more plausible. Since Turkey is a developing country, it is endowed with relatively more

\footnotetext{
${ }^{15}$ See appendix 4.1 for the method.
} 
unskilled labor ${ }^{16}$. We expect that increased trade (the foreign demand) makes Turkey produce and export more unskilled-labor intensive products. Hence we expect $\beta_{4}$ to be negative. On the other hand import may have the same effect with capital stock since firms import intermediary and invest goods.

Before going further, let's examine the relationship between technology and labor variables.

Figure 4.4: Correlation Between Changes in Nonproduction Workers and Changes in R\&D Expenditures

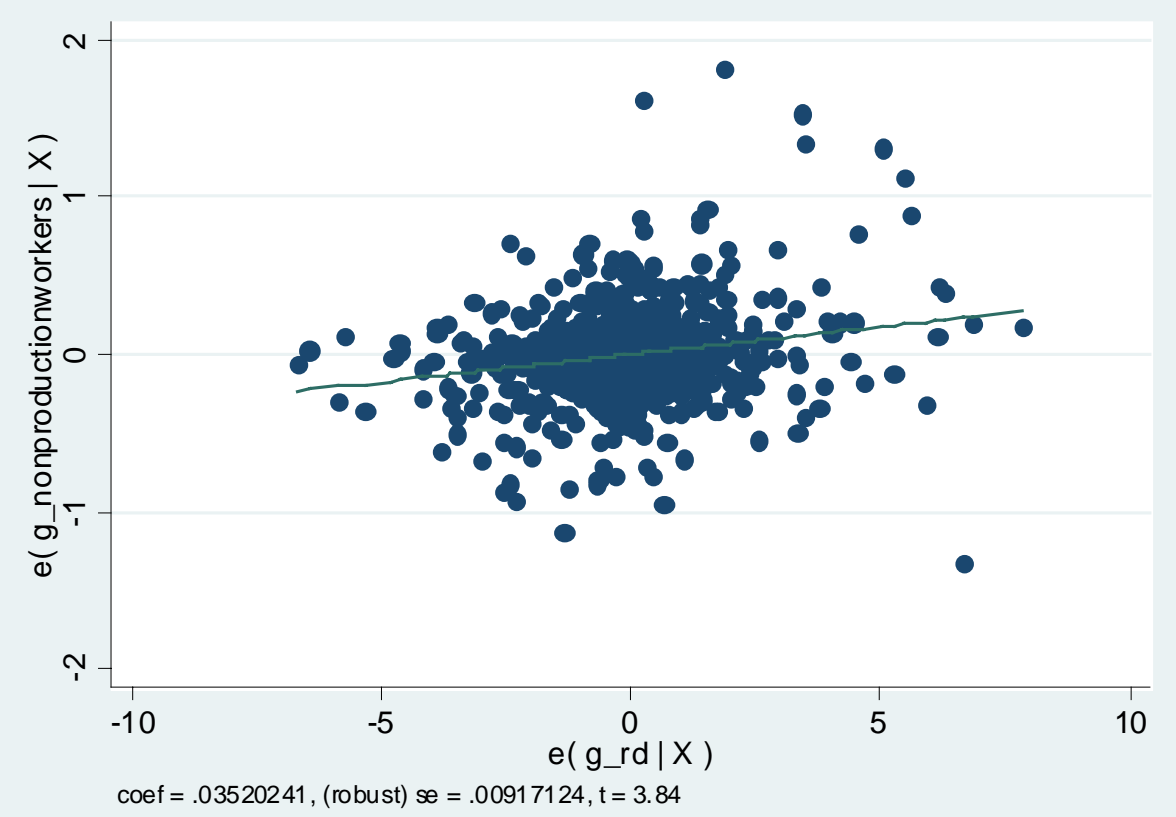

\footnotetext{
${ }^{16}$ This assumption is not implausible. According to World Development Indicators, in 1998, labor force with primary education in U.K and U.S. is $20 \%$ and $14 \%$ respectively. Whereas, in Mexico and Turkey, it is equal to $70 \%$ and $74 \%$ respectively.
} 
Figure 4.5: Correlation Between Changes in Nonproduction Workers and Changes in Computer and Software Investments

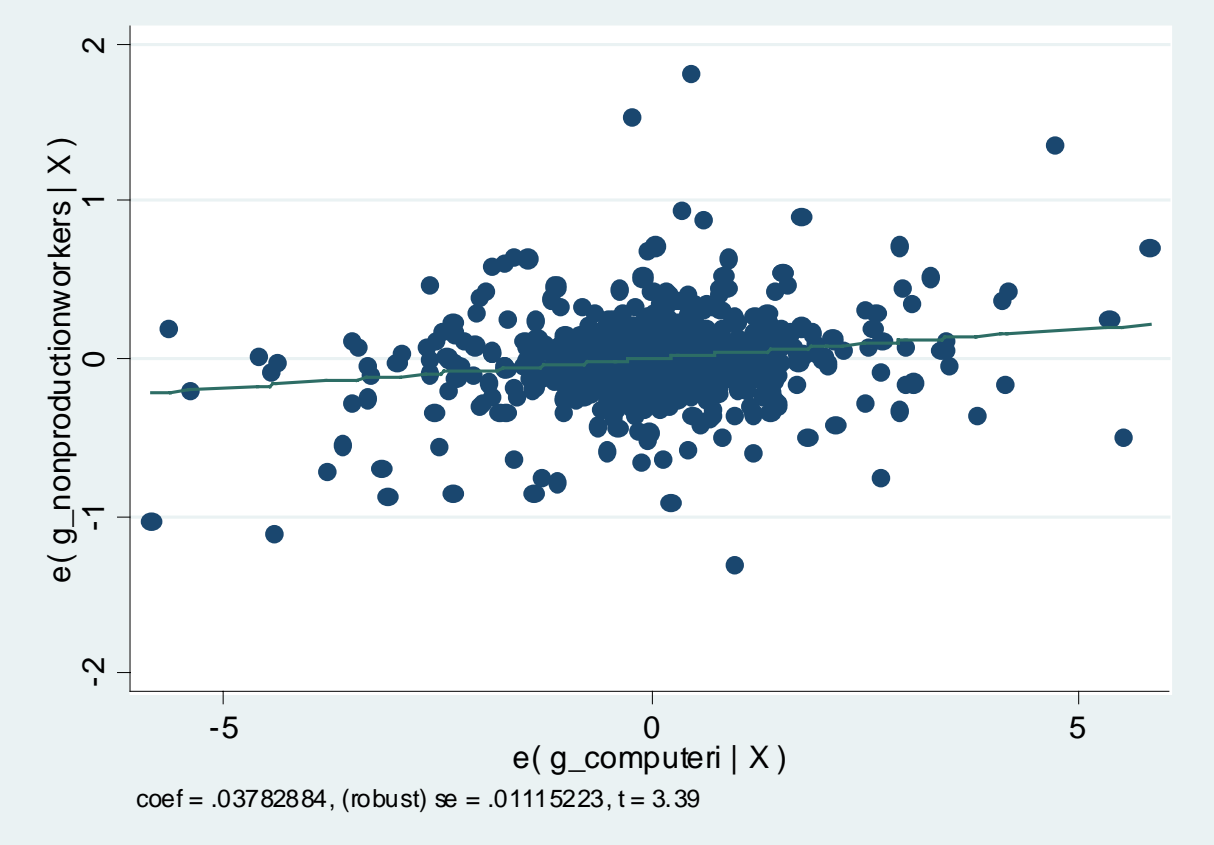

Figures 4.4 and 4.5 represent the relationship between technology variables and nonproduction workers. The two technology variables are positively correlated with nonproduction labor and have zero p-values. It looks like that there is very strong relation between these variables. 
Figure 4.6: Correlation Between Changes in Technical Workers and Changes in R\&D Expenditures

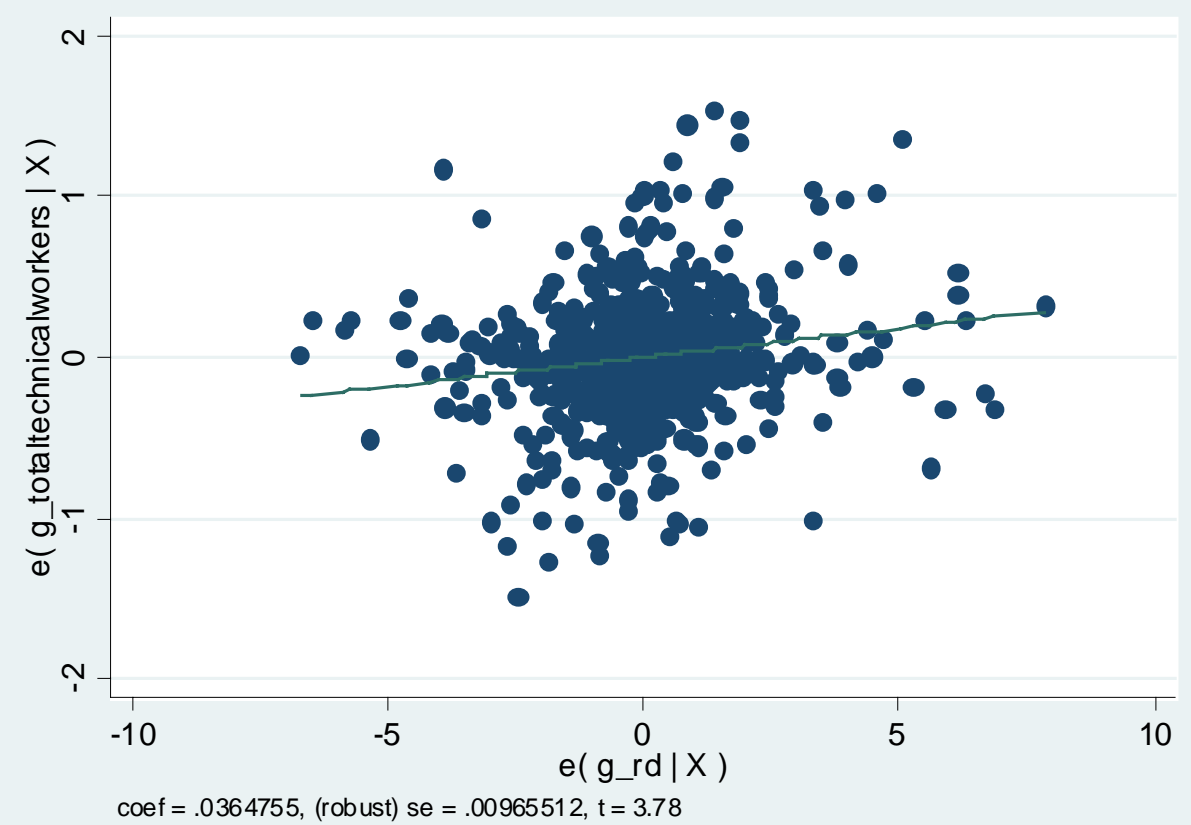

Figure 4.7 Correlation Between Changes in Technical Workers and Changes in Computer and Software Investments

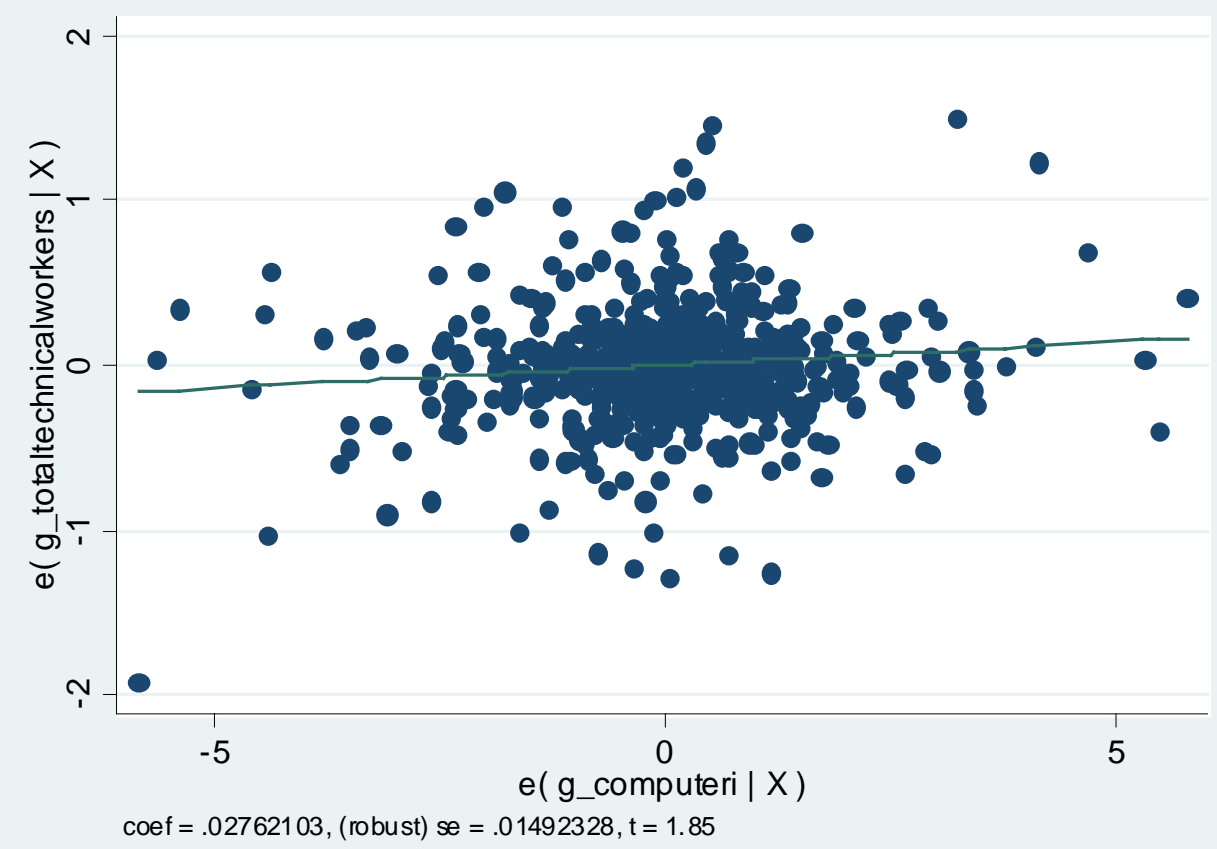


Figure 4.6 and 4.7 present the relationship between technology variables and technical workers. For both of the technology variables, the relationships with technical workers are positive. $R \& D$ and investments in computer and software variables are significant with zero and $0.06 \mathrm{p}$-values respectively. Consequently, the relation between R\&D expenditures and technical workers seems less strong when compared with nonproduction workers.

The previous studies which use occupational data deal with nonproduction labor as skilled labor and production labor as an unskilled labor. Although this method is open question, we follow the same methodology in order to compare our results with other studies. Empirical results for equation 9 are presented in table 4.1.

$$
S_{\text {nonpit }}=\delta+\beta_{1} \ln Y_{i t}+\beta_{2} \ln K_{i t}+\beta_{3} \text { Tech }_{i t}+\beta_{4} \text { Openness }_{i t}+\varepsilon_{i t},
$$

where; $S_{\text {nonpit }}$ is the share of nonproduction workers in total workers,

$Y_{i t}$ is the output,

$K_{i t}$ is the capital stock,

$\operatorname{Tech}_{i t}{ }^{R \& D}$ is R\&D intensity and $T e c h_{i t}{ }^{\text {Computer }}$ ICTs intensity,

Openness $_{i t}$ is the export intensity. 
Table 4.1: Estimating Nonproduction Labor Share Using Different Regression Models

$\begin{array}{cccccc}\text { OLS } & \text { FE } & \text { RE } & \text { OLS } & \text { FE } & \text { RE } \\ (1) & (2) & (3) & (4) & (5) & (6)\end{array}$

Independent Variables

$\begin{array}{lcccccc}\text { Constant } & -16.47 & -15.28 & -18.72 & -6.13 & -5.51 & -10.68 \\ \mathrm{~K} & (0.00) & (0.03) & (0.00) & (0.13) & (0.62) & (0.13) \\ & -0.74 & 0.29 & 0.17 & -0.86 & -0.61 & -0.72 \\ \mathrm{Y} & (0.00) & (0.06) & (0.25) & (0.00) & (0.19) & (0.05) \\ & 4.58 & 3.90 & 3.33 & 4.24 & 3.22 & 3.80 \\ \text { Tech }^{\text {R\&D }} & (0.00) & (0.00) & (0.00) & (0.00) & (0.00) & (0.00) \\ & 0.64 & -0.17 & -0.12 & & & \\ \text { Tech }{ }^{\text {Computer }} & (0.07) & (0.54) & (0.62) & & & \\ & & & & 0.04 & -0.29 & -0.27 \\ \text { Openness } & & & & (0.17) & (0.62) & (0.63) \\ & -0.0008 & 0.0003 & 0.0003 & -0.04 & 0.005 & 0.003 \\ \text { Year Dummies } & (0.30) & (0.28) & (0.30) & (0.00) & (0.49) & (0.65) \\ \text { Industry Dummies } & \text { Yes } & \text { Yes } & \text { Yes } & \text { Yes } & \text { Yes } & \text { Yes } \\ \text { Yes } & & & \text { Yes } & & \\ \text { Diagnostic Statistics } & & & & & & \\ \text { R-square } & & & & & & \\ \text { Observations } & 0.34 & 0.23 & 0.24 & 0.34 & 0.25 & 0.26 \\ \text { Hausman Test } & 1068 & 1068 & 1068 & 749 & 749 & 749 \\ & & \text { p-value=0.08 } & & & \\ \end{array}$

Based on heteroscedasticity robust standard errors. p-values are in parentheses. Columns 1, 2, and 3 cover $1992-2001$ period and 4, 5, and 6 cover 1995-2001 period. 
Ordinary Least Squares (OLS) estimation results indicate that R\&D intensity is positive and significant, however, ICTs intensity is positive and insignificant. In both estimates output is positive and significant with zero p-value. Capital, on the other hand, significant but has negative sign. Openness is insignificant in column 1 but significant in column 4. Moreover, the sign is negative and the same in both of the models.

Although the results were depicted in table 4.1, OLS estimation is only relevant when we assume; $\varepsilon_{i t} \sim \operatorname{iid}\left(0, \sigma^{2}\right)$ for all $i$ and $t$. That is, for a given individual, observations are serially uncorrelated; and across individuals and time, the errors are homoscedastic. However, with this assumption, we have essentially ignored the panel structure of the data (Johnston and Dinardo, 1997, p.390). Taking into consideration the panel structure of the data, we estimated the below equation;

$$
S_{\text {nonpit }}=\delta+\beta_{1} \ln Y_{i t}+\beta_{2} \ln K_{i t}+\beta_{3} \text { Tech }_{i t}+\beta_{4} \text { Openness }_{i t}+\varepsilon_{i t}
$$

where

$$
\varepsilon_{i t}=\alpha_{i}+\lambda_{t}+\eta_{i t}, i=1, \ldots, N ; t=1, \ldots, T
$$

where $\alpha_{i}$ denotes the unobservable individual effect, $\lambda_{t}$ denotes the unobservable time effect and $\eta_{i t}$ is the remainder stochastic disturbance term. $\lambda_{t}$ is individual-invariant 
and it accounts for any time specific effect that is not included in the regression (Baltagi, 2005, p.33). We included it in our regression since in the examined period there are two crisis years. We have two alternatives while estimating equation 10; either Fixed Effects (FE) or Random Effects (RE) models. The main difference between these models is that in RE model, we assume that the unobservable individual effect $\alpha_{i}$ is uncorrelated with explanatory variables. Whereas, in FE model, $\alpha_{i}$ is correlated with explanatory variables. The usual way to choose FE or RE is to perform Hausman test ${ }^{17}$. In table 4.1, we presented the results of the both models.

For the estimates of equation 10, Hausman test indicates FE model due to the rejection of null hypothesis. In FE models, $\mathrm{Y}$ is positive and significant with zero pvalue. $\mathrm{K}$ is positive and significant in column 2 , however, negative and insignificant in column 5. Other explanatory variables are insignificant. In RE models, Y is still positive and significant with zero p-value. $\mathrm{K}$ is significant in column 6 but has negative sign. Although we expect positive and significant technology variables, neither R\&D nor ICTs intensity is significant.

Alternatively, we can define technical workers in manufacturing industries as skilled labor and investigate the relationship between technological progress and these workers. The equation we will estimate is the following;

$$
S_{\text {techit }}=\delta+\beta_{1} \ln Y_{i t}+\beta_{2} \ln K_{i t}+\beta_{3} \text { Tech }_{i t}+\beta_{4} \text { Openness }_{i t}+\varepsilon_{i t} \text {, }
$$

\footnotetext{
${ }^{17}$ If the null hypothesis is rejected, FE model is chosen. However, if the null hypothesis is accepted RE model is chosen. See Hausman (1978)
} 
where; $S_{\text {techit }}$ is the share of technical workers in total workers,

$Y_{i t}$ is the output,

$K_{i t}$ is the capital stock,

$T_{e c h_{i t}}{ }^{R \& D}$ is R\&D intensity and $T e c h_{i t}{ }^{\text {Computer }}$ is ICTs intensity,

Openness $_{i t}$ is the export intensity.

Estimation results for equation 12 are presented in table 4.2 
Table 4.2: Estimating Technical Labor Share Using Different Regression Models

$\begin{array}{cccccc}\text { OLS } & \text { FE } & \text { RE } & \text { OLS } & \text { FE } & \text { RE } \\ (1) & (2) & (3) & (4) & (5) & (6)\end{array}$

Independent Variables

$\begin{array}{lcccccc}\text { Constant } & 8.93 & 4.78 & 3.54 & 8.90 & 10.4 & 6.85 \\ & (0.00) & (0.13) & (0.07) & (0.00) & (0.11) & (0.05) \\ \mathrm{K} & -0.23 & 0.24 & 0.08 & -0.29 & 0.36 & -0.05 \\ & (0.00) & (0.01) & (0.35) & (0.00) & (0.14) & (0.79) \\ \mathrm{Y} & 0.29 & -0.12 & 0.16 & 0.47 & -0.72 & 0.07 \\ & (0.00) & (0.68) & (0.37) & (0.00) & (0.10) & (0.78) \\ \text { Tech }^{\text {R\&D }} & 0.95 & 0.19 & 0.30 & & & \\ & (0.00) & (0.30) & (0.15) & & & \\ \text { Tech }^{\text {Computer }} & & & & 0.03 & 0.74 & 0.86 \\ & & & & (0.08) & (0.10) & (0.07) \\ \text { Openness } & -0.00007 & 6.53 \mathrm{e} & -6.95 \mathrm{e} & -0.01 & -0.007 & -0.003 \\ & (0.80) & (0.97) & (0.97) & (0.00) & (0.04) & (0.21) \\ \text { Year Dummies } & \text { Yes } & \text { Yes } & \text { Yes } & \text { Yes } & \text { Yes } & \text { Yes } \\ \text { Industry Dummies } & \text { Yes } & & & \text { Yes } & & \\ & & & & & & \\ \text { Diagnostic Statistics } & & & & & & \\ \text { R-square } & 0.33 & 0.003 & 0.07 & 0.28 & 0.02 & 0.07 \\ \text { Observations } & 1068 & 1068 & 1068 & 749 & 749 & 749 \\ \text { Hausman Test } & & \text { p-value }=0.03 & & \text { p-value=0.03 }\end{array}$

Based on heteroscedasticity robust standard errors. p-values are in parentheses. Equations 1, 2, and 3 cover $1992-2001$ period and 4, 5, and 6 cover 1995-2001 period. 
OLS estimation results indicate that capital is significant and negatively related with technical workers share. Output is positive and significant, however, the magnitude is very low when it is compared with the results of table 4.1. Both R\&D and ICTs intensity is positive and significant although the latter has a high p-value-0.08.

Just like equation 10, equation 12 has panel data structure. Therefore we estimated FE and RE models and performed Hausman test. Since the null hypothesis is rejected FE model is chosen. In FE results of column 2, capital is positive and significant, however, in column 5, capital is positive and insignificant. Output is negative and insignificant in column 2 but negative and significant in column 5. R\&D intensity is positive but insignificant, however, ICTs intensity is positively related with technical workers share despite high p-value- 0.10 . Finally, openness is positive and insignificant in column 2, whereas, negative and insignificant in column 5.

In RE results of column 3, none of the explanatory variables are significant. On the other hand, in column 6 , only ICTs intensity is positive and significant.

These results can be interpreted as follows:

1. Although the literature employs nonproduction labor as skilled labor, it is not appropriate for Turkish case. The estimation results clearly highlights that technological progress is not related with nonproduction labor share. On the other hand, output variable has positive and quite strong relationship with nonproduction labor share. These results are not 
surprising and occur as a result of the size effect. Since nonproduction labor consists of management and administrative personnel, such as officers, managers, accountants, sales persons and secretaries, bigger firms employ more managers, accountants and even more drivers. For this reason it is plausible to explain the nonproduction labor share with the size effect.

2. When we employ technical workers as skilled labor the estimation results change. First, R\&D intensity is insignificant, which may be the cause of quite low R\&D expenditures of Turkish manufacturing industries when compared with other countries. Second, ICTs intensity is positive and significant despite $0.10 \mathrm{p}$-value. The high $\mathrm{p}$-value indicates that there is a weak relationship between technological progress and skilled labor share.

3. The FE estimation results of column 2 in table 4.2 supports capital-skill complementarity. However $\mathrm{K}$ is insignificant in column 5 and $\mathrm{RE}$ models. Moreover, it is negative and significant with zero p-value in OLS models. These results represent conflicting results for capital-skill complementarity in Turkish private manufacturing industries.

4. Openness is only significant in column 4 and 5 with negative sign. As the capital variable, these results are not robust and there is not a clear relationship between foreign trade and skilled labor in Turkish private manufacturing industries. 


\section{CONCLUSION}

There are two significant features of the Industrial Revolution. First, it became possible to establish factories, thanks to the use of steam energy. Second, standardization in production emerged as the interchangeable parts came to be produced. Craftsmen could maintain their existence till the end of nineteenth century by working at factories despite the mechanization of production in the early Industrial Revolution. Because of that, second half of the nineteenth century may be described as a late craft system. But, as interchangeable parts were put in use, the need for skilled workers disappeared, as it was possible to standardize production only by employing unskilled workers. In other words, the Industrial Revolution embodied a de-skilling characteristic.

ICTs Revolution has different characteristics when compared with Industrial Revolution. The former occurred in the second half of the twentieth century, and it has completely changed the standardized formation of production and rendered possible the production of commodities for diversified consumer demands. That change in the form of production has required the workforce that is more educated and able to use computer technologies. In other words, ICTs Revolution has possessed a skill-bias as a feature

As a result of this skill bias, demand for skilled labor increased in developed countries for three decades. Most of the empirical studies singled out technological 
progress as a determinant of this increasing demand for skilled labor. In this study, nonproduction labor was defined as skilled labor to establish a basis of comparison with the other studies. However, econometric results indicate that nonproduction labor is not related to technological progress but strongly related to output volume of the industries. Although, the results are in contradiction to the other studies, it is not much of a surprise. Because the nonproduction workers consist of the managers, accountants, sales persons etc., more output volume requires more nonproduction workers.

Alternatively, when technical workers in manufacture industries are defined as skilled labor, there is a weak but positive relationship between technological development and skilled labor. It can be put forward that, for the Turkish case, the more realistic approach would be to define skilled workers over technical workers, rather than nonproduction workers.

Finally, in Turkey, SBTC hypothesis is not as clear as it is in the developed countries. The low level of R\&D expenditures and investments in computers and software seems to be the cause of this weak relation. 


\section{APPENDICES}

Appendix 3.1: Employees

\section{A- PRODUCTION WORKERS:}

\section{Technical Personnel:}

a) High level technical personnel: Without regarding the type of profession, employees such as engineers and the like who manage and orientate the production for which they are highly responsible.

b) Medium level technical personnel: Without regarding the type of profession, employees trained at a certain level who manage and orientate the production for which they are responsible.

2. Formen, supervisors and other skilled workers: Those who are responsible for the distribution of the work and controlling the quality of the work done.

3. Unskilled Workers: Persons who work physically in production and people other than listed above.

\section{B- ADMINISTRATIVE AND OTHER EMPLOYEES:}

1. Management and administrative personnel: High level paid administrators who are responsible for the management of the establishment, having authority for the representing the establishment and signing documents. Their technical training background does not affect their quality of being administrative personnel.

2. Officers: Accountant, cashier, secretary, salesperson, typist etc. and the personnel who work in health and educational services of establishment.

3. Other Employees: Workers other than mentioned above: Loading, unloading and storage workers, drivers, door keepers, quards, representatives. 


\section{Appendix 3.2: International Standard Industrial Classification of Manufacturing Industries (ISIC, Rev.3)}

15 Manufacture of food products and beverages

151 Production, processing and preservation of meat, fish, fruit, vegetables, oils and fats

1511 Production, processing and preserving of meat and meat products

1512 Processing and preserving of fish and fish products

1513 Processing and preserving of fruit and vegetables

1514 Manufacture of vegetable and animal oils and fats

152 Manufacture of dairy products

1520 Manufacture of dairy products

153 Manufacture of grain mill products, starches and starch products, and prepared animal feeds

1531 Manufacture of grain mill products

1532 Manufacture of starches and starch products

1533 Manufacture of prepared animal feeds

154 Manufacture of other food products

1541 Manufacture of bakery products

1542 Manufacture of sugar

1543 Manufacture of cocoa, chocolate and sugar confectionery

1544 Manufacture of macaroni, noodles, couscous and similar farinaceous products

1549 Manufacture of other food products n.e.c.

155 Manufacture of beverages

1551 Distilling, rectifying and blending of spirits; ethyl alcohol production from fermented materials

1552 Manufacture of wines

1553 Manufacture of malt liquors and malt

1554 Manufacture of soft drinks; production of mineral waters

16 Manufacture of tobacco products

160 Manufacture of tobacco products

1600 Manufacture of tobacco products

17 Manufacture of textiles

171 Spinning, weaving and finishing of textiles

1711 Preparation and spinning of textile fibres; weaving of textiles

1712 Finishing of textiles

172 Manufacture of other textiles

1721 Manufacture of made-up textile articles, except apparel

1722 Manufacture of carpets and rugs

1723 Manufacture of cordage, rope, twine and netting

1729 Manufacture of other textiles n.e.c.

173 Manufacture of knitted and crocheted fabrics and articles

1730 Manufacture of knitted and crocheted fabrics and articles

18 Manufacture of wearing apparel; dressing and dyeing of fur

181 Manufacture of wearing apparel, except fur apparel

1810 Manufacture of wearing apparel, except fur apparel

182 Dressing and dyeing of fur; manufacture of articles of fur

1820 Dressing and dyeing of fur; manufacture of articles of fur

19 Tanning and dressing of leather; manufacture of luggage, handbags, saddlery, harness and footwear

191 Tanning and dressing of leather; manufacture of luggage, handbags, saddlery and harness

1911 Tanning and dressing of leather

1912 Manufacture of luggage, handbags and the like, saddlery and harness

192 Manufacture of footwear

1920 Manufacture of footwear

20 Manufacture of wood and of products of wood and cork, except furniture; manufacture of articles of straw and plaiting materials

201 Sawmilling and planing of wood 
Sawmilling and planing of wood

Manufacture of products of wood, cork, straw and plaiting materials

Manufacture of veneer sheets; manufacture of plywood, laminboard, particle board and other panels and boards

Manufacture of builders' carpentry and joinery

Manufacture of wooden containers

Manufacture of other products of wood; manufacture of articles of cork, straw and plaiting materials

Manufacture of paper and paper products

Manufacture of paper and paper products

Manufacture of pulp, paper and paperboard

Manufacture of corrugated paper and paperboard and of containers of paper and paperboard

Manufacture of other articles of paper and paperboard

Publishing, printing and reproduction of recorded media

Publishing

Publishing of books, brochures, musical books and other publications

Publishing of newspapers, journals and periodicals

Publishing of recorded media

Other publishing

Printing and service activities related to printing

Printing

Service activities related to printing

Reproduction of recorded media

Reproduction of recorded media

Manufacture of coke, refined petroleum products and nuclear fuel

Manufacture of coke oven products

Manufacture of coke oven products

Manufacture of refined petroleum products

Manufacture of refined petroleum products

Processing of nuclear fuel

Processing of nuclear fuel

Manufacture of chemicals and chemical products

Manufacture of basic chemicals

Manufacture of basic chemicals, except fertilizers and nitrogen compounds

Manufacture of fertilizers and nitrogen compounds

Manufacture of plastics in primary forms and of synthetic rubber

Manufacture of other chemical products

Manufacture of pesticides and other agro-chemical products

Manufacture of paints, varnishes and similar coatings, printing ink and mastics

Manufacture of pharmaceuticals, medicinal chemicals and botanical products

Manufacture of soap and detergents, cleaning and polishing preparations, perfumes and toilet preparations

Manufacture of other chemical products n.e.c.

Manufacture of man-made fibres

Manufacture of man-made fibres

Manufacture of rubber and plastics products

Manufacture of rubber products

Manufacture of rubber tyres and tubes; retreading and rebuilding of rubber tyres

Manufacture of other rubber products

Manufacture of plastics products

Manufacture of plastics products

Manufacture of other non-metallic mineral products

Manufacture of glass and glass products

Manufacture of glass and glass products 
269 Manufacture of non-metallic mineral products n.e.c.

2691 Manufacture of non-structural non-refractory ceramic ware

2692 Manufacture of refractory ceramic products

2693 Manufacture of structural non-refractory clay and ceramic products

2694 Manufacture of cement, lime and plaster

2695 Manufacture of articles of concrete, cement and plaster

2696 Cutting, shaping and finishing of stone

2699 Manufacture of other non-metallic mineral products n.e.c.

27 Manufacture of basic metals

271 Manufacture of basic iron and steel

2710 Manufacture of basic iron and steel

272 Manufacture of basic precious and non-ferrous metals

2720 Manufacture of basic precious and non-ferrous metals

273 Casting of metals

2731 Casting of iron and steel

2732 Casting of non-ferrous metals

28 Manufacture of fabricated metal products, except machinery and equipment

281 Manufacture of structural metal products, tanks, reservoirs and steam generators

2811 Manufacture of structural metal products

2812 Manufacture of tanks, reservoirs and containers of metal

2813 Manufacture of steam generators, except central heating hot water boilers

289 Manufacture of other fabricated metal products; metal working service activities

2891 Forging, pressing, stamping and roll-forming of metal; powder metallurgy

2892 Treatment and coating of metals; general mechanical engineering on a fee or contract basis

2893 Manufacture of cutlery, hand tools and general hardware

2899 Manufacture of other fabricated metal products n.e.c.

29 Manufacture of machinery and equipment n.e.c.

291 Manufacture of general purpose machinery

2911 Manufacture of engines and turbines, except aircraft, vehicle and cycle engines

2912 Manufacture of pumps, compressors, taps and valves

2913 Manufacture of bearings, gears, gearing and driving elements

2914 Manufacture of ovens, furnaces and furnace burners

2915 Manufacture of lifting and handling equipment

2919 Manufacture of other general purpose machinery

292 Manufacture of special purpose machinery

2921 Manufacture of agricultural and forestry machinery

2922 Manufacture of machine-tools

2923 Manufacture of machinery for metallurgy

2924 Manufacture of machinery for mining, quarrying and construction

2925 Manufacture of machinery for food, beverage and tobacco processing

2926 Manufacture of machinery for textile, apparel and leather production

2927 Manufacture of weapons and ammunition

2929 Manufacture of other special purpose machinery

293 Manufacture of domestic appliances n.e.c.

2930 Manufacture of domestic appliances n.e.c.

30 Manufacture of office, accounting and computing machinery

300 Manufacture of office, accounting and computing machinery

3000 Manufacture of office, accounting and computing machinery

31 Manufacture of electrical machinery and apparatus n.e.c.

311 Manufacture of electric motors, generators and transformers

3110 Manufacture of electric motors, generators and transformers 
312 Manufacture of electricity distribution and control apparatus

3120 Manufacture of electricity distribution and control apparatus

313 Manufacture of insulated wire and cable

3130 Manufacture of insulated wire and cable

314 Manufacture of accumulators, primary cells and primary batteries

3140 Manufacture of accumulators, primary cells and primary batteries

315 Manufacture of electric lamps and lighting equipment

3150 Manufacture of electric lamps and lighting equipment

319 Manufacture of other electrical equipment n.e.c.

3190 Manufacture of other electrical equipment n.e.c.

32 Manufacture of radio, television and communication equipment and apparatus

321 Manufacture of electronic valves and tubes and other electronic components

3210 Manufacture of electronic valves and tubes and other electronic components

322 Manufacture of television and radio transmitters and apparatus for line telephony and line telegraphy

3220 Manufacture of television and radio transmitters and apparatus for line telephony and line telegraphy

323 Manufacture of television and radio receivers, sound or video recording or reproducing apparatus, and associated goods

3230 Manufacture of television and radio receivers, sound or video recording or reproducing apparatus, and associated goods

33 Manufacture of medical, precision and optical instruments, watches and clocks

331 Manufacture of medical appliances and instruments and appliances for measuring, checking, testing, navigating and other purposes, except optical instruments

3311 Manufacture of medical and surgical equipment and orthopaedic appliances

3312 Manufacture of instruments and appliances for measuring, checking, testing, navigating and other purposes, except industrial process control equipment

3313 Manufacture of industrial process control equipment

332 Manufacture of optical instruments and photographic equipment

3320 Manufacture of optical instruments and photographic equipment

333 Manufacture of watches and clocks

3330 Manufacture of watches and clocks

34 Manufacture of motor vehicles, trailers and semi-trailers

341 Manufacture of motor vehicles

3410 Manufacture of motor vehicles

342 Manufacture of bodies (coachwork) for motor vehicles; manufacture of trailers and semi-trailers

3420 Manufacture of bodies (coachwork) for motor vehicles; manufacture of trailers and semi-trailers

343 Manufacture of parts and accessories for motor vehicles and their engines

3430 Manufacture of parts and accessories for motor vehicles and their engines

35 Manufacture of other transport equipment

351 Building and repairing of ships and boats

3511 Building and repairing of ships

3512 Building and repairing of pleasure and sporting boats

352 Manufacture of railway and tramway locomotives and rolling stock

3520 Manufacture of railway and tramway locomotives and rolling stock

353 Manufacture of aircraft and spacecraft

3530 Manufacture of aircraft and spacecraft

359 Manufacture of transport equipment n.e.c.

3591 Manufacture of motorcycles

3592 Manufacture of bicycles and invalid carriages

3599 Manufacture of other transport equipment n.e.c.

36 Manufacture of furniture; manufacturing n.e.c.

361 Manufacture of furniture 
3610 Manufacture of furniture

369 Manufacturing n.e.c.

3691 Manufacture of jewellery and related articles

3692 Manufacture of musical instruments

3693 Manufacture of sports goods

3694 Manufacture of games and toys

3699 Other manufacturing n.e.c.

37 Recycling

371 Recycling of metal waste and scrap

3710 Recycling of metal waste and scrap

372 Recycling of non-metal waste and scrap

3720 Recycling of non-metal waste and scrap 
Appendix 3.3: Classification of Manufacturing Industries Based on Technology (R\&D)

$\underline{\text { ISIC Rev.3 }}$

High-technology industries

Aircraft and spacecraft 353

Pharmaceuticals 2423

Office, accounting and computing machinery $\quad 30$

Radio, TV and communication equipment 32

Medical, precision and optical instruments 33

\section{Medium-high-technology industries}

Electrical machinery and apparatus, n.e.c. 31

Motor vehicles, trailers and semi-trailers 34

Chemicals excluding pharmaceuticals 24 excl. 2423

Railroad equipment and transport equipment, n.e.c. $\quad 352+359$

Machinery and equipment, n.e.c.

Medium-low-technology industries

Building and repairing of ships and boats 351

Rubber and plastic products 25

Coke, refined petroleum products and nuclear fuel 23

Other non-metallic mineral products 26

Basic metals and fabricated metal products $\quad 27-28$

\section{Low-technology industries}

Manufacturing, n.e.c; Recycling 36-37

Wood, pulp, paper, paper products, printing and publishing 20-22

Food products, beverages and tobacco 15-16

Textiles, textile products, leather and footwear $17-19$

Total Manufacturing

Source: OECD Report, 2005. 
Appendix 3.4: Classification of Manufacturing Industries Based on Technology (ICTs)

\section{$\underline{\text { ISIC Rev.3 }}$}

\section{ICT-producing manufacturing}

30 Office, accounting and computing machinery

313 Insulated wire and cable

321 Semiconductors and other electronic components

322 Communication and broadcasting equipment

323 Radio and TV receivers

$331 \quad$ Medical and measuring equipment and industrial process control

\section{ICT-using manufacturing}

18 Wearing apparel, dressing and dying of fur

$22 \quad$ Printing and publishing

29 Machinery and equipment

31, excl. 313 Electrical machinery and apparatus, excluding insulated wire

33, excl. 331 Presicion and optical instruments, excluding ICT instruments

351 Building and repairing of ships and boats

353 Aircraft and spacecraft

$352+359$ Railroad equipment and transport equipment

36-37 Miscellaneous manufacturing and recycling

\section{Less-intensive-ICT-using manufacturing}

15-16 Food products, beverages and tobacco

17 Textiles

19 Leather, leather products and footwear

20 Wood and products of wood and cork

21 Pulp, paper and paper products

23 Coke, refined petroleum products and nuclear fuel

24 Chemicals and chemical products

25 Rubber and plastic products

26 Non-metallic mineral products

27 Basic metals

$28 \quad$ Fabricated metal products

34 Motor vehicles, trailers and semi-trailers

Source: Ark, B.V. et. al. 2003. 
Appendix 4.1: Perpetual Inventory Method

The equation that used to calculate capital stock is;

$K_{t}=I_{t}+(1-\delta) K_{t-1}$,

where $\mathrm{K}$, I and $\delta$ are capital stock, investments and depreciation rate respectively. Depreciation rate is assumed to be 0.05 for all sectors and years. In this method, initial level of capital stock is calculated with the below formula;

$K_{0}=\frac{I_{0}}{g+\delta}$

in this formula, $g$ is the rate of growth of output over the period. However, we use 19922000 period to calculate the growth rate since 2001 is a crisis year. 


\section{REFERENCES}

Acemoglu, D., 1998. "Why do New Technologies Complement Skills? Directed Technical Change and Wage Inequality," The Quarterly Journal of Economics, Vol. 113, No. 4, pp. 1055-1089

Acemoglu, D., 2002. "Technical Change, Inequality, and The Labor Market," Journal of Economic Literature, Vol. 40, No. 1, pp. 7-72

Allen, J., 1996. "Fordism and Modern Industry," in Hall, S., Held, D., Hubbert, D., and Thompson, K. (Eds.) Modernity: An Introduction To Modern Societies, Blackwell Publishing, pp. 280-307

Ark, B.V., Inklaar, R., McGuckin and H.R., 2003. "Changing Gear: Productivity, ICT and Service Industries in Europe and the United States," in Christensen, J., F., and Maskell, P. (Eds.) The Industrial Dynamics of the New Digital Economy, Edward Elgar, pp. 56-99

Autor, D.H., Katz, F.L. and Krueger, A.B., 1998. "Computing Inequality: Have Computers Changed The Labor Market," The Quarterly Journal of Economics, Vol. 113, No. 4, pp. $1169-1213$

Ayres, R.U., 1991. Computer Integrated Manufacturing, Vol. 1, Chapman and Hall, London

Barro, R.J. and Sala-i-Martin, X., 2004. Economic Growth, Second Edition, The MIT Press, Cambridge, Massachusetts

Bartel, A.P. and Lichtenberg, F.R., 1987. "The Comparative Advantage of Educate Workers in Implementing New Technology," The Review of Economics and Statistics, Vol.69, No. 1, pp. 146-150

Berman, E., Bound, J. and Griliches, Z., 1994. "Changes in the Demand for Skilled Labor within U.S. Manufacturing: Evidence from the Annual Survey of Manufactures," The Quarterly Journal of Economics, Vol. 109, No. 2, pp. 367-397

Betts, J.R., 1997. "The Skill Bias of Technological Change in Canadian Manufacturing Industries," The Review of Economics and Statistics, Vol.79, No. 1, pp. 1-11

Caselli, F., 1999. "Technological Revolutions," American Economic Review, Vol. 89, No. 1, pp. 78-102

Christensen, L.R., Jorgensen, D.W., and Lau, L.J., 1973. "Transcendantal Logarithmic Production Frontiers", Vol. 55, No. 1, pp. 28-45 
Christensen, L.R. and Greene, W.H., 1976. "Economies of Scale in U.S. Electric Power Generation," The Journal of Political Economy, Vol. 84, No. 4, pp. 655-676

Coombs, R., Saviotti, P. and Walsh, V., 1987. Economics and Technological Change, Rowman and Littlefield, New Jersey

Diebold, J., 1952. Automation: The Advent of the Automatic Factory, New York: van Nostrand

Dinardo, J. and Johnston, J., 1997. Econometric Methods, International Editions, The McGraw-Hill Companies, Singapore

Doğruel, A., S. and Doğruel, F., 2008. Türk Sanayiine Sektörel Baklş, TÜSİAD-T/2008 05/466, İstanbul

Doms, M., Dunne, T. and Troske, K.R., 1997. "Workers, Wages, and Technology," The Quarterly Journal of Economics, Vol. 112, No. 1, pp. 253-290

Duruiz, L., and Yentürk, N., 1992. Facing The Challenge: Turkish Automobile, Steel and Clothing Industries To The Post-Fordist Restructuring, İletişim Yayınları, İstanbul

Freeman, C., 2002. As Time Goes By: From the Industrial Revolutions to the Information Revolution, Electronic Source, $<$ http:/www.oxfordscholarship.com/oso/public/content/economicsfinance/9780199251056/ toc.html $>$ (accessed 2 May 2008)

Freeman, C. and Soete, L., 2000. The Economics of Industrial Innovation, Continuum, London

Freeman, R.B., 1995. "Are Your Wages Set in Beijing," The Journal of Economic Perspectives, Vol. 9, No. 3, pp. 15-32

Gera, S., Gu, W. and Zhengxi, L., 2001. "Technology and Demand For Skill in Canada: An Industry Level Analysis," Canadian Journal of Economics, Vol. 34, No. 1, pp. 132-148

Goldin, C., and Katz, L.F., 1998. "The Origins of Technology Skill Complementarity," The Quarterly Journal of Economics, Vol. 113, No. 3, pp. 693-732

Güran, T., 1999. İktisat Tarihi, Acar Matbaacılık, İstanbul

Hausman, J., A., 1978. "Specification Tests in Econometrics," Econometrica, Vol. 46, No. 6, pp. 1251-1271

Katz, L., F., 2000. "Technological Change, Computerization and The Wage Structure," in Brynjolfsson, E., and Kahin, B. (Eds.) Understanding The Digital Economy: Data, Tools, and Research, MIT Press, Cambridge, pp. 217-244 
Kepenek, Y. and Yentürk, N., 2004. Türkiye Ekonomisi, Remzi Kitabevi, İstanbul

Kızılırmak, B., 2003. "Explaining Wage Inequality: Evidence From Turkey," Discussion Paper, <http://www.politics.ankara.edu.tr/dosyalar/tm/SBF WP 57.pdf $>$ (accessed 27 October 2007)

Kmenta, J., 1967. "On Estimation of the CES Production Function," International Economic Review, Vol. 8, No. 2, pp. 180-189

Machin, S. and Van Reenen, J., 1998. "Technology and Changes in Skill Structure: Evidence From Seven OECD Countries," The Quarterly Journal Of Economics, Vol. 113, No. 4, pp. 1215-1244

Malecki, E.J., 1997. Technology and Economic Development: The Dynamics of Local, Regional and National Competitiveness, Longman, Essex

OECD Report, 2003a. Employment Outlook, Electronic Source,

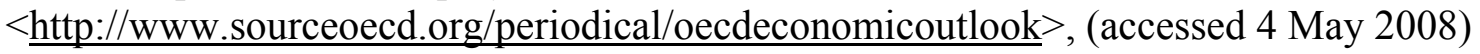

OECD Report, 2003b. ICT and Economic Growth: Evidence from OECD Countries, Industries and Firms, Electronic Source, $<$ http://fiordiliji.sourceoecd.org/vl=3766476/cl=53/nw=1/rpsv/cgibin/fulltextew.pl?prpsv=/ij/oecdthemes/99980134/v2003n8/s2/p1l.idx $>$, (accessed 4 May 2008)

OECD Report, 2004a. Employment Outlook, Electronic Source,

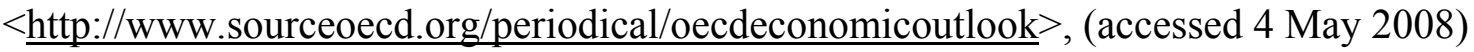

OECD Report, 2004b. Information Technology Outlook, Electronic Source, $<$ http://fiordiliji.sourceoecd.org/vl=3766476/cl=53/nw=1/rpsv/cgibin/fulltextew.pl?prpsv=/ij/oecdthemes/99980134/v2004n15/s1/p1l.idx $>$, (accessed 4 May 2008)

OECD Report, 2005. OECD Science, Technology and Industry Score, 2005, Towards a knowledge-based economy, Electronic Source, $<$ http://fiordiliji.sourceoecd.org/vl=3766476/cl=53/nw=1/rpsv/cgibin/fulltextew.pl?prpsv=/ij/oecdthemes/99980134/v2005n15/s1/p1l.idx $>$, (Accessed 4 May 2008)

OECD.Stat-Organization for Economic Co-operation and Development, $<\underline{\text { http://stats.oecd.org }>\text { (accessed } 6 \text { May, 2008) }}$

O'Mahony, M., and Ark, B.V., 2004, "EU Productivity and Competitiveness: An Industry Perspective," $<$ http://europa.eu.int/comm/enterprise/enterprise policy/competitiveness/doc/ eu_competitiveness_a_sectoral_perspective.pdf $>$ (accessed 22 May 2008) 
Piore, M.J. and Sabel, C.F., 1984. The Second Industrial Divide: Possibilities for Prosperity, Basic Books, New York

Piva, M. and Vivarelli, M., 2002. "The Skill Bias: Comparative Evidence and An Econometric Test," International Review of Applied Economics, Vol. 16, No. 3, pp. 347357.

Ricardo, D., 2001. On the Principles of Political Economy and Taxation, Ch. XXXI (On Machinery), p. 391-404, Electronic Source, $<$ http://fiordiliji. sourceoecd.org/vl=3766476/cl=53/nw=1/rpsv/cgibin/fulltextew.pl?prpsv=/ij/oecdthemes/99980134/v2005n15/s1/p11.idx $>$, (accessed 1 June 2008)

Sakurai, K., 2001. "Biased Technological Change and Japanese Manufacturing Employment," Journal of the Japanese and International Economies, Vol. 15, No. 3, pp. 298-322

Schmookler, J., 1966. Invention and Economic Growth, Harvard University Press, Cambridge

Slaughter, M.J., 1998. "What are the Results of Product-Price Studies and What Can We Learn From Their Differences?” NBER Working Paper No: 6591

Slaughter, M., 1999. "Globalization and Wages: A Tale of Two Perspectives," World Economy, Vol. 22, No. 5, pp. 609-629.

SPO-Undersecreteriat of State Planning Organization, < http://www.spo.gov.tr $>$ (accessed 4 April, 2008)

Stoneman, P., 1983. The Economic Analysis of Technological Change, Oxford University Press, New York

Taymaz, E., 1998. "Technological Change and Employment in Turkish Manufacturing Industries," in Bulutay, T. (Ed.) Technology and Employment, SIS, Ankara, pp. 186-224

TURKSTAT-Turkish Statistical Institute, 2006. Statistical Indicators (1923-2005). http://www.turkstat.gov.tr (accessed 10 December 2007).

Türkcan, E., 1981. Teknolojinin Ekonomi Politiği, AİTİA Yayınları, Ankara

Womack, J.T., Jones, D.T. and Roos, D., 1990. The Machine that Changed the World, Rawson Associates, New York

World Development Indicators,

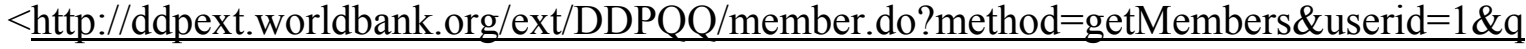
ueryId=6>, (accessed 1 June 2008) 